\title{
PIRMOJO PASAULINIO KARO VEIKSMAI VAKARU LIETUVOJE - VOKIETIJOS IR RUSIJOS PASIENYJE - 1915 M. PRADŽIOJE
}

\author{
Marius Pečiulis \\ Vytauto Didžiojo karo muziejus
}

\section{IVADAS}

1914 m. prasidejęs Pirmasis pasaulinis karas turejo tapti žaibo karu. Nė viena kariaujanti pusè nesitikejjo, kad jis gali trukti ilgiau nei kelias savaites arba - blogiausiu atveju - kelis mènesius. Tačiau greito karo planai lygiai taip pat greitai ir žlugo. Praktiškai nuo pirmujų mūšių tapo aišku, jog Vokietija nesugebės kariauti dviem frontais. Pagal išankstini planą turejusi eliminuoti savo priešininkus Vakaruose, o tik tada permesti pagrindines pajėgas kovoti su Rusija ị Rytų frontą, ji tai buvo priversta padaryti jau pirmojo kovų mènesio pabaigoje. Taigi $1915 \mathrm{~m}$. pradžioje iš esmès situacija liko nepakitusi. Žymių postūmių, galinčių lemti karo baigtí, neicvyko nei dèl vienos, nei dèl kitos kariaujančios pusės veiksmų. Tačiau Vokietija vis dar nesirengė atsisakyti žaibo karo planų. Perèjusi prie pozicinio karo Vakarų fronte, ji sutrauké pagrindines pajėgas i rytus, kad eliminuotu iš kovos Rusijos imperiją. Žiemos pabaigoje arba pavasario pradžioje turejo prasidèti naujas Vokietijos pajègu žygis. Tiesa, vis dar vyko ginčai, kurioje fronto dalyje šis lemiamas smūgis turi būti smogtas: šiauriau, judant per Lietuvą gilyn ị carinès Rusijos imperiją, ar pietuose - kad kartu galima būtuc padèti ir Austrijai-Vengrijai.

Rusijos imperijos okupuotos Lietuvos žemès buvo Vokietijos pasienyje, tad, savaime suprantama, Pirmojo pasaulinio karo kovos nuo pat pirmuju dienų vyko ir mūsų krašte. 1914 m. mūšiai vyko pasienyje ir Pietų Lietuvoje: atskiri Vokietijos kariuomenès daliniai netgi sugebejo pasiekti Druskininkus ir Alytaus apylinkes. 1915 m. situacija visiškai pasikeite - karo audros jau buvo apimta visa šiandieninès Lietuvos teritorija.

Šiame darbe nesistengsime apžvelgti visų Pirmojo pasaulinio karo kovu Lietuvos teritorijoje, o pabandysime panagrinèti tik vieną jų epizodą. Skaitant tiek Rusijos, tiek Vokietijos istorijos tyrejuc veikalus galima pastebėti, kad daugiausia dèmesio sutelkta būtent ị 1915 m. pradžioje Rusijos ir Vo- 
kietijos pasienyje, i pietus nuo Nemuno žemupio, vykusias kovas. Aišku, tuo nereikètų stebėtis - kaip tik čia žygiavo ir i pagrindinius mūšius stojo Vilniuje suformuota 1-oji Rusijos armija. Tačiau iš karto kyla klausimas: kas tuo metu vyko Žemaitijos laukuose į šiaurès vakarus nuo Nemuno žemupio - Rusijos ir Vokietijos pasienyje? Juk čia buvo du svarbūs Vokietijos miestai - Klaipèda ir Tilžè. Pirmasis saugojo prieigą prie Baltijos jūros, iš kurios vandens kelias vedè i Kuršių marias ir per jas ị Nemuno upę. Užèmus Tilžę, Rusijos kariuomenei gerai išplètotu Vokietijos geležinkelių tinklu nesunku būtų buvę patekti tiesiai ị Karaliaučių.

Taigi šio darbo tikslas - apžvelgti Pirmojo pasaulinio karo kovas Vakaru Lietuvoje - Vokietijos ir Rusijos pasienyje 1915 m. pradžioje. Chronologinès ribos pasirinktos neatsitiktinai. $1915 \mathrm{~m}$. balandžio pabaigoje būtent Vakarų Lietuvoje prasidèjo plataus masto Vokietijos pajègų puolimas siekiant iš šiaurès pusès užpulti Kauno tvirtovę ir atsidurti Rusijos 10-osios armijos užnugaryje. Šiame darbe reikètų apžvelgti šio puolimo priešistorę: kas čia vyko iki tol, kol buvo sutelktos gausios tiek vienos, tiek kitos pusės pajègos. Tiesa, nesistengsime labai griežtai laikyti minètų ribų, įsisprausti į chronologinius rèmus. Vis dèlto negalime pradèti nuo $1915 \mathrm{~m}$. neatskleidę, kas šiame fronto ruože vyko nuo pat karo pradžios. Todèl nedidelę šio darbo dalį sudarys karo veiksmų Vakarų Lietuvoje 1914 m. apžvalga.

Šaltinių ir istoriografijos nagrinejjama tema ištekliai ypač negausūs. Autorius dèl objektyvių priežasčių neturejo galimybių prisiliesti prie Vokietijos ir Rusijos archyvuose saugomų informacijos klodų, kur būtų galima rasti šiam darbui aktualiausios informacijos. Tad pagrindinę istorinès medžiagos dali, panaudotą rašant darbą, sudaro Rusijos ir Vokietijos istorijos tyrejuc istoriografinès pozicijos, to laikotarpio periodiniai leidiniai ir memuarai.

Tiesa, negalime sakyti, kad mums niekuo negalejo pagelbèti Lietuvos archyvai. Šiek tiek vertingos informacijos rašant šị darbą, ypač bandant lokalizuoti atskirus karinius konfliktus bei nustatyti jų datą, radome Kauno apskrities archyve (toliau - KAA), Kauno gubernatoriaus kanceliarijos fonde (Канцелярия Ковенского гражданского губернатора), kur saugomos pasienio apskričių policijos viršininkų telegramos ir pranešimai apie karinius veiksmus fronte ${ }^{1}$.

Daugiausia informacijos aptariamaja tema pateikia to meto periodiniai leidiniai: Rygos garsas, Lietuvos žinios ir kt. Siekdami sudaryti atsvarą Rusijos imperijoje leistiems lietuviškiems laikraščiams, naudojomès Rytų Prūsijoje leista lietuviška ir vokiška spauda: Lietuwiszka ceitunga, Tilsiter algemeine zeitung. Tiesa, i periodikos informaciją reikia žiūrèti labai atsargiai: vis dèlto negalima

1 KAA, f. 50, ap. 2, b. 199, 200. 
pamiršti, kad didžioji dabartinès Lietuvos dalis tuo metu priklausė carinès Rusijos imperijai, kai daugelyje gyvenimo sričių, taip pat ir spaudoje, būta daugybès įvairių suvaržymų, kurie karo metu buvo dar labiau sugriežtinti.

Taip pat vertingų žinių suteikia tuo metu gyvenusių žmonių liudijimai. Ypač vertingi Vokietijos Rytų fronto štabo narių gen. mjr. Ėricho Liudendorfo (Erich Ludendorff) ${ }^{2}$ ir gen. mjr. Makso Hofmano (Max Hoffmann) ${ }^{3}$ atsiminimai. Iš šio žanro leidinių verta išskirti lietuvių Antano Gintnerio ${ }^{4}$, taip pat Petro Rusecko surinktus gyventoju atsiminimus ${ }^{5}$.

Istoriografijoje apie kovas Vakarų Lietuvoje taip pat labai mažai rašoma. Autoriui nepavyko rasti lietuviškos istoriografijos pozicijų, kuriose būtų išsamiai kalbama apie Pirmojo pasaulinio karo kovas šioje Lietuvos dalyje. Ne ką daugiau pavyko sužinoti ir skaitant Rusijos autorių darbus: juose apie kovas prie Klaipėdos ir Tauragès užsimenama labiau fragmentiškai. Šiek tiek bendro pobūdžio informacijos galima rasti A. Kersnovskio (А. Керсновский $)^{6}$, A. Neznamovo $(\text { А. Незнамов })^{7}$, A. Strokovo $(\text { А. Строков })^{8}$, A. Zajončkovskio (А. Зайончковский $)^{9}$, I. Rostunovo (И. И. Ростунов $)^{10}, \mathrm{~K}$. Zaleskio (K. А. Залесский $)^{11}$ ir kitų autorių darbuose. Iš Rusijos tyrèjų vertètų iškirti Albertą Adilovą (Альберт Адылов). Laikraštyje „Kaliningrado tiesa“ (Калининградская правда) išspausdintas jo nedidelis mūšiui prie Klaipèdos skirtas straipsnelis ${ }^{12}$.

Kur kas daugiau aktualios informacijos rašant Pirmojo pasaulinio karo

E. Ludendorff, Meine kriegserinnerungen 1914-1918, Berlin, 1919.

3 М. Гофман, Записки и дневники 1914-1918, Ленинград, 1929; М. Гофман. Война упущенных возможностей. Ленинград, 1925.

4 A. Gintneris, Lietuva caro ir kaizerio naguose, Čikaga, 1970.

5 Lietuva Didžiajame kare, sudar. P. Ruseckas, Vilnius, 1939.

6 А. А. Керсеновский, История Русской армии, Москва, 1999.

7 А. Незнамов, Стратегический очерк войны 1914-1918 г. Период с 12 (25) ноября 1914 г. по 15 (28) марта 1915 г., ч. 3, Москва, 1922.

8 А. А. Строков, Вооруженные силы и военное искусство в Первой мировой войне, Москва, 1974.

9 А. М. Зайончковский, Первая мировая война, Санкт-Петербург: Полигон, 2002.

10 И. И. Ростунов, Русский фронт Первой мировой войны, Москва: Наука, 1976.

11 К. А. Залесский, Первая мировая война. Правители и военоначальники, Вече, Москва, 2000, с. 496.

12 А. Адылов, Третий штурм // Калининградская правда, 12 марта // http://www.kaliningradka.ru/newshow.php?newsid=37766; Friedrich Immanuel. Der Krieg im Herbst und Winter im Osten. Der deutsche Landkrieg, Erster Teil: Vom Kriegsbeginn bis zum Frühjahr 1915 // Der Weltkampf um ehre und recht, baden 1, kapitel 7 // http://www.wintersonnenwende.com/scriptorium/ deutsch/archiv/weltkampf/wer0133.html; Der Erste Weltkrieg - 1914/1918 // http://www.1914-18. info/erster-weltkrieg.php? $\mathrm{u}=349 \&$ info $=6$. Kavallerie-Division \&start $=70$ 
kovų Vakarų Lietuvoje tematika randame vokiečių istoriografijoje. Ypač vertingi aptariamuju ivvykių liudininko, Klaipedos krašto gyventojo Johano Zembrickio (Johannes Sembritzki) veikalai ${ }^{13}$. Juose autorius nuosekliai aprašo to meto îvykius ne tik Klaipėdos mieste, bet ir visame Klaipédos krašte. Faktografinès medžiagos apie kovas Rytų Prūsijoje yra Schlachtfelder in Ostpreussen ${ }^{14}$ leidinyje, prie Klaipèdos - interneto svetainėse, kur pateikti Vokietijos autorių darbai ${ }^{15}$. Kitomis akimis i mūšius dẻl Tauragès leidžia pažvelgti Pirmojo pasaulinio karo metu išleista karo kronika ${ }^{16}$.

Taigi, naudodamiesi aptartais šaltiniais ir istoriografijos pozicijomis šiame darbe mes pabandysime išspręsti šiuos uždavinius:

- trumpai apžvelgsime, kaip rutuliojosi Pirmojo pasaulinio karo veiksmai Vakarų Lietuvoje nuo pat jo pradžios iki metų pabaigos;

- aptarsime, kokius puolimo planus kūrè kariaujančios pusės 1915 m. pradžioje;

- plačiau patyrinèsime mūšių dèl Tauragès ir Klaipėdos miestų aplinkybes.

Rašant darbą, lokalizuojant ịvairias vietoves, bus naudojami tik šiandieniniai miestų ir miestelių pavadinimai. Visos datos bus rašomos naujuoju stiliumi, naudojant Grigaliaus kalendorių.

\section{KARINIAI VEIKSMAI JURBARKO-KLAIPE்DOS LINIJOJE NUO KARO PRADŽIOS IKI 1914 M. PABAIGOS}

1914 m. rugpjūčio viduryje, dar iki galo nebaigus formuoti Lietuvoje dislokuotos 1-osios armijos, Rusijos daliniai peržengė Vokietijos sieną. Tai ir buvo šių didžiųu pasaulio valstybių aktyvių karo veiksmų pradžia ${ }^{17}$. Rugpjūčio 17 d. ịvyko kautynės prie Stalupėnų (dabar Nesterovas, Kaliningrado sritis) ${ }^{18}$, rugpjūčio 20 d. - prie Gumbinès (dabar Gusevas, Kaliningrado sritis $)^{19}$. Pagrindine puolimo kryptimi neatsitiktinai pasirinkta Virbalio, Stalupènų, Gumbinès, o vèliau, savaime suprantama, Karaliaučiaus kryptis. Tai teritorijos, per kurias buvo nutiesta Kauno-Karaliaučiaus geležinkelio linija,

\footnotetext{
13 J. Sembritzki, Geschichte des kreises Memel, Memel, 1918; J. Sembritzki, Geschichte des kreises Heydekrug, Memel, 1920.

14 Schlachtfelder in Ostpreussen, 2 auflage, Königsberg, 1932, s. 153

15 Der russische Raubzug gegen Memel. Berichte aus dem deutschen Großen Hauptquartier 1914-1918. Das Archiv zum 1. Weltkrieg // http://www.stahlgewitter.com/weltkrieg/1915_memel.htm

16 War Chronicle. War Journal. Soldiers, letters, pictures of the war. April 1915, p. 1 // http:// www.archive.org/stream/warchroniclesold041915berluoft\#page/n3/mode/2up

17 Iš Lietuvos // Rygos garsas, 1914, liepos 26 (rugpjūčio 8), Nr. 59, p. 3.

18 Radus-Zenkavičius, Susitinkamujų kautynių bruožai, Kaunas, 1921, p. 11.

19 Ten pat.
} 
Sankt Peterburgo-Varšuvos geležinkelio atšaka. XX a. pradžioje sausumos transportas buvo palyginti menkai išplètotas, taigi geležinkelis buvo pagrindinè gija, garantuojanti veikiančiosios kariuomenès visapusi aprūpinimą.

Galime teigti, kad būtent dèl šios priežasties teritorija šiauriau nuo Nemuno žemupio - Mažosios Lietuvos žemès - atsidūre aktyviausių karo veiksmų zonos nuošalyje. Tačiau atidžiau pastudijavę šaltinius, be gausios informacijos, skirtos pirmujų karo dienų vaizdui nupiešti, užtiksime ir menkučių žinučių, leidžiančių suprasti, kad karo šmėkla neaplenkè ir šios teritorijos. Štai 1914 m. liepos 26 d. (pagal naujaji kalendorių - rugpjūčio 8 d.) laikraštyje Rygos garsas skelbiama, kad „Vokietijos kariuomene susprogdino plenta пио Palangos ligi Klaipeddos giliais ravais; padirbo pylimus, kad sutrukdžius kelia rusu kariuomenei" ${ }^{20}$.

Vokietija ruošèsi galimam Rusijos puolimui, tačiau iš čia dislokuotų dalinių skaičiaus matyti, kad ji nuspejjo svarbiausias priešininko puolimo kryptis ir pagrindines pajègas telke kitose vietose. Šioje Nemuno žemupio linijoje Vokietijos pasienio su Rusija apsaugos dalinius sudare 2-oji landvero ${ }^{21}$ brigada, vadovaujama plk. Hugo fon Lupino (Hugo von Lupin $)^{22}$, dislokuota prie Tilžès, ir jungtiniai landšturmo ${ }^{23}$ batalionai. Rugpjūčio 17 d. šios negausios pajègos dar labiau susilpnèjo, kai 2-oji landvero brigada nužygiavo prie Gumbinès, kad padètų ten besikaunančiai Vokietijos 8-ajai armijai ${ }^{24}$.

Rusija taip pat šiame ruože buvo dislokavusi tik pasienio apsaugos dalinius: 5-ąą Gargždų pasienio apsaugos brigadą, kurios štabas buvo Kretingoje, ir 6-ają Tauragès pasienio apsaugos brigadą, kurios štabas buvo įsikūręs Taurageje, taip pat 5-aji Gargždų pasienio apsaugos ir 6-aji Tau-

20 Iš Lietuvos // Rygos garsas, 1914, liepos 26 (rugpjūčio 8), Nr. 59, p. 3.

21 Landveras (vok. Landwehr - krašto gynyba) - antraeilio karinio rezervo daliniai. I landverą buvo šaukiami arba dar neįtraukti ị reguliariosios kariuomenès rezervą jaunuoliai, arba vyresni vyrai, jau atitarnavę jame. Žr. Большая Советская Энциклопедия // http://bse.sci-lib.com/ article068595.html

22 2-ają landvero brigadą sudarè 4-asis ir 33-iasis landvero pèstininkų pulkai, 2-asis landvero eskadronas ir 2-oji landvero baterija. Žr.: http://www.tannenberg1914.de/5_armeen/deutsch.htm

23 Landšturmas (vok. Landsturm - krašto puolimas) - kariuomenès rezervas, šaukiamas tik karo metu. Tai pagalbiniai daliniai, daugiausia formuojami iš vyrų, dėl kokių nors priežasčių atleistų nuo karo tarnybos, tačiau fiziškai vis dar jai tinkamų. Žr. Большая Советская Энциклопедия // http://bse.sci-lib.com/article068595.html

24 Schlachtfelder in Ostpreussen, s. 153. 


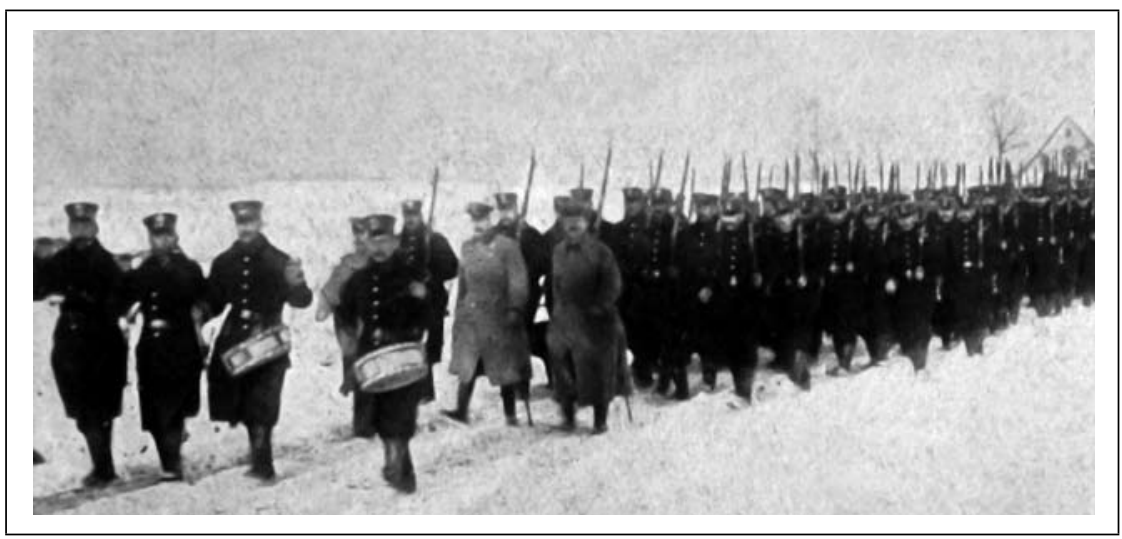

Vokietijos landšturmo daliniai žygyje (VDKM)

ragès pasienio apsaugos raitelių pulkus ${ }^{25}$. Būtent Vilniaus karinès apskrities pasieniečiai vieni pirmujų Rusijos kariuomenejje pateko ị karo veiksmų sūkurị. Pirmieji šio karo metu nukauti Rusijos kariai buvo 6-osios Tauragès pasienio apsaugos brigados štabo rotmistras Spiridonas Rambidis (Спиридон Панаиотович Рамбиди) ir vachmistras (?) Pristyžniukas $(\text { Пристыжнюк })^{26}$.

Tiesa, tik prasidejus karui šiame regione esantys pasienio apsaugos daliniai sulaukè pastiprinimo, kadangi čia buvo dislokuota 68-oji pèstininkų divizija, vadovaujama gen. mjr. Aleksandro Apuchtino (Александр Апухтин), susidedanti iš antraeilių ${ }^{27}$ 269-ojo Novorževo, 270-ojo Gatčinos,271-ojo

25 Abi šios brigados priklausè 2-ajai Vilniaus pasienio apsaugos apskričiai. Ši apskritis buvo sukurta 1899 m. vasario 1 d. Rusijos caro Nikolajaus II ịsakymu. Pasienio apsaugos apskričiai, be minètų brigadų, priklausė 7-oji Virbalio pasienio apsaugos brigada, kurios štabas buvo Kybartuose, 8-oji Grajevo pasienio apsaugos brigada (štabas Grajeve) ir 9-oji Lomžos pasienio pasaugos brigada (štabas Lomžoje). Vilniaus karinès apskrities valdybą 1915 m. perkèlus į Daugpili, pasieniečiams taip pat iš ten buvo vadovaujama. Žr. Фонды управлений, соединений и частей пограничной и внутренней стражи, местных войск, воинских начальников, жандармских, карательных и дисциплинарных частей. Раздел 13 // Путеводители по архивам России // http:/guides.rusarchives.ru/browse/guidebook. html?bid=239\&sid $=829209$

\section{6 А. А. Керсеновский, История Русской армии, с. 495.}

27 Po Rusijos-Japonijos karo (1904-1905 m.), reformuojant Rusijos kariuomenę, 1910 m. buvo formuojami antros eilès daliniai. Tokia reforma buvo atlikta siekiant padidinti mobilizuojamu karių skaičių. Antros eilès daliniai buvo sudaromi iš antrojo šaukimo atsargos karių, todèl, savaime suprantama, jų kovinè parengtis buvo gerokai prastesnè. 
Krasnoselsko ir 272-ojo Gdovo pėstininkų pulkų ${ }^{28}$. 68-oji pėstininkų divizija buvo suformuota tik karo metu, jos štabas ịsikūre Šiauliuose ${ }^{29}$.

Abi valstybès dar tik buvo pradejusios mobilizuoti savo kariuomenes, o pasienyje jau vyko pirmieji kariniai susidūrimai. Rugpjūčio 2 d. Rusijos pasienio apsaugos daliniai peržengè valstybes skiriančią sieną tiek Klaipèdos, tiek Silutès apskrityse ir pradejo plèšikauti pasienio kaimuose: Kretingaleje, Laugaliuose, Doviluose, Žemaitkiemyje ir kt. ${ }^{30}$ Suvaldyti krašte plěšikaujančius priešininkus ị Dovilus geležinkeliu buvo nusiųstas 41-ojo pėstininkų pulko 3-iasis batalionas, tačiau Rusijos kariai jau buvo pasitraukę. Rusijos ir Vokietijos karių susidūrimas tą pačią dieną ịvyko prie Vilkyčių, kur kpt. (?) Hoislerio (Häusler) vadovaujama 80 karių grupe ne tik išstūmė iš krašto plèšikaujančius Rusijos karius, bet dar ir paèmé i nelaisvę

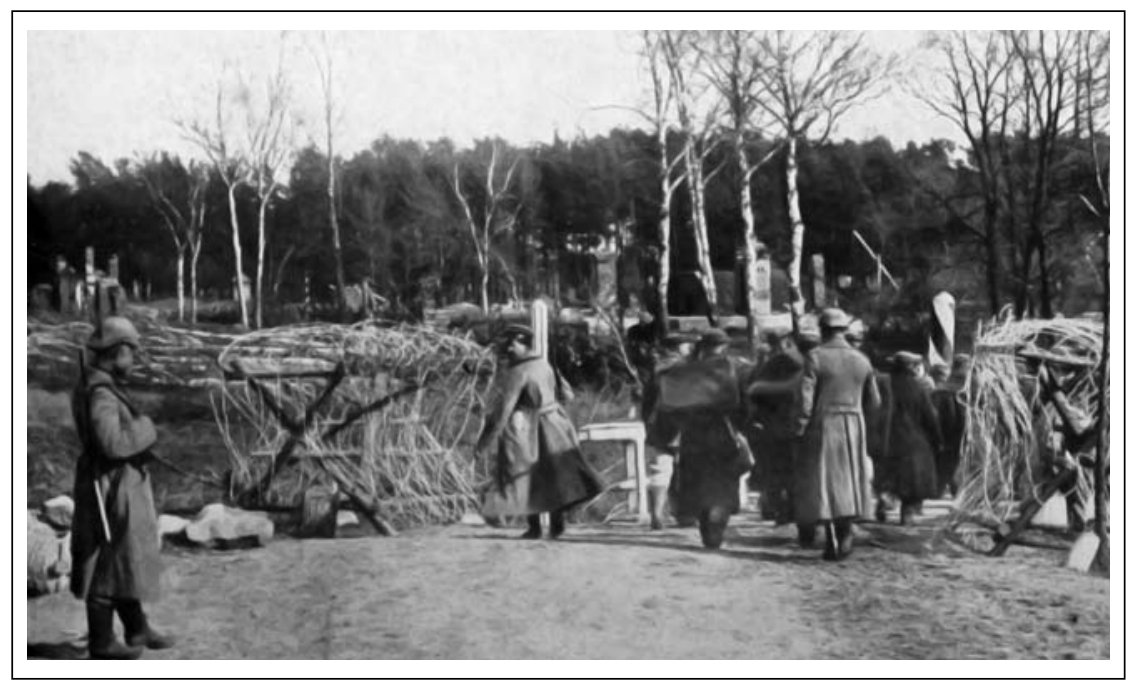

Rusijos ir Vokietijos pasienio postas prie Smalininkų. 1914 m. (VDKM)

4 kazokus $^{31}$. Rugpjūčio 4 d. Klaipèdos pasienio apsaugos dalinys prie Kretin-

28 А. А. Строков, Вооруженные силы и военное искусство в Первой мировой войне, с. 142; И. И. Ростунов. Русский фронт Первой мировой войны , Москва: Наука, 1976, с. 209.

29 А. Незнамов, Стратегический очерк войны 1914-1918 г. Период с 12 (25) ноября 1914 2. по 15 (28) мapma 1915 2., c. 65.

30 J. Sembritzki, Geschichte des kreises Memel, s. 381.

31 J. Sembritzki, Geschichte des kreises Heydekrug, s. 279. 
galès atstūmė atgal už sienos rusų žvalgus ${ }^{32}$. Keletas kariaujančių pusių susidūrimų ịvyko rugpjūčio 8-12 dienomis, kai landvero daliniai susigrūmė su Rusijos kariais prie Smalininkų (dabar Jurbarko r.), Lauksargių (dabar Tauragès r.), Viešvilès (dabar Jurbarko r.), Katyčių (dabar Šilutès r.) ${ }^{33}$. Tačiau visais šiais atvejais Rusijos žvalgai buvo nustumti atgal už valstybės sienos. Rugpjūčio 8 d. susirèmimo prie Laugalių metu Vokietija šiame rajone patyré pirmuosius nuostolius. Pirmas užmuštas klaipėdietis buvo vyr. ltn. Maras Fišeris (Mar Fischer), tarnavęs 2-osios péstininkų divizijos 3-iosios pèstininkų brigados 33-iajame fuzilierių grafo Ronio (Roone) pulke ${ }^{34}$.

Padètis pasikeitè minètą 2-ają landvero brigadą perdislokavus prie Gumbinès. Netekusios rimtos paspirties, Vokietijos pajègos nesugebejjo pasipriešinti gausesniam priešininkui - i Klaipėdos kraštą iž̌engè Rusijos kariai. Rusijos 1-oji armija puolẻ plačiu frontu, pagrindinę jègą sutelkusi pasienyje ties Kybartais, o jos kraštiniame, dešiniajame, sparne žygiavo jau minètoji 8-oji pėstininkų divizija, sustiprinta pasienio apsaugos daliniais. Neturèdama jègos persvaros, Vokietijos karinè vadovybė sutelkẻ dalinius prie Šilutės ir Klaipėdos ${ }^{35}$. Taip stengtasi neleisti priešininkui užvaldyti Nemuno upés žiočių, tačiau, kita vertus, teko paaukoti Tilžès miestą. Neturẻdami galimybių tinkamai pasipriešinti, Vokietijos kariai bande bent jau apsunkinti Rusijos kariuomenès žygi pasinaudodami gamtine kliūtimi Nemuno upe. Naktị iš rugpjūčio 24-osios i 25-ają Vokietijos inžineriniai daliniai ruošèsi susprogdinti abu tiltus per Nemuno upę prie Tilžès, tačiau, įsikišus miesto burmistrui, šio sumanymo buvo atsisakyta. Tik Nemuno upès vagoje buvo paskandinta keletas garlaivių, kad sutrukdytų Rusijos karinių laivų judejjimą ${ }^{36}$. Numatant neišvengiamą priešininko ịsiveržimą i i Tilžę stengtasi iš miesto evakuoti kuo daugiau materialiųjų išteklių, kad jie neatitektų Rusijos kariams. Dar rugpjūčio 24 d. iš Tilžès ị Rusnę buvo išvežti 26 automobiliai, ginklai ir amunicija, išplukdyti upių laivai ir garlaiviai, prikrauti medienos ir metalo krovinių, išgabenta daug kitų naudingų daiktų ${ }^{37}$.

32 Oberst Rudolf Frantz, Der Sommerfeldzug in Ostpreußen 1914 // Der Weltkampf um ehre und recht, bd. 1, kapitel 5. http://clarysmith.com/scriptorium/deutsch/archiv/weltkampf/wer0120.html

33 Schlachtfelder in Ostpreussen, s. 153.

34 J. Sembritzki, Geschichte des kreises Memel, s, 383.

35 Ten pat.

36 Tilžès paėmimas // Rygos garsas, 1914, rugpjūčio 30 (rugsèjo 12), Nr. 59, p. 2.

37 J. Sembritzki, Geschichte des kreises Heydekrug, s. 280. 


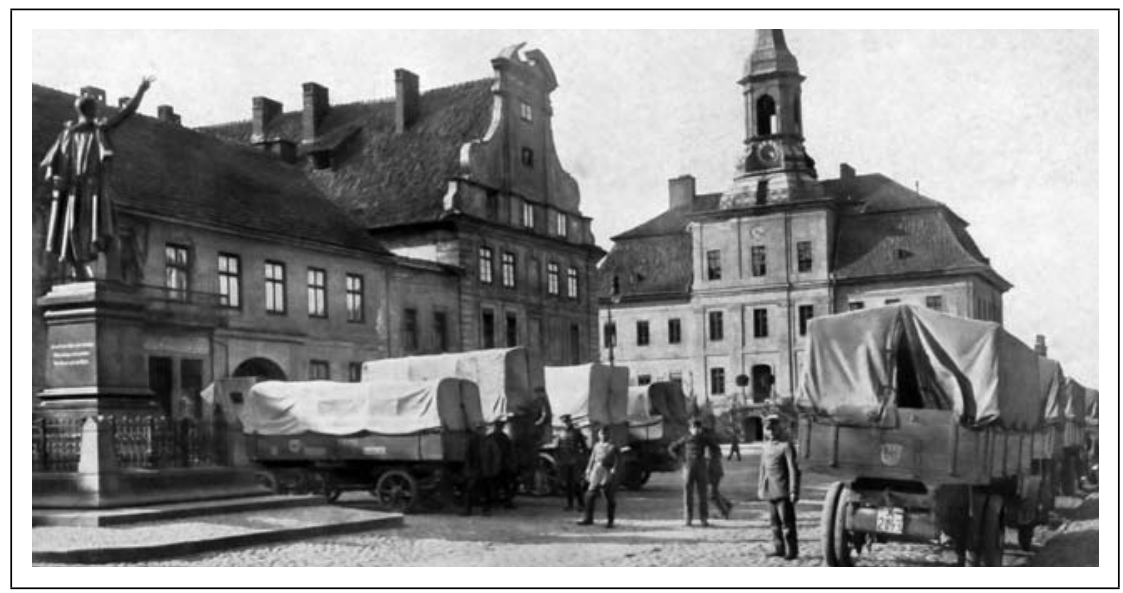

Vokietijos kariuomenès sunkvežimiai ir vežimai Tilžès turgaus aikštèje. 1914 m. (VDKM)

Rugpjūčio 26 d. čia jau šeimininkavo svetima kariuomené $\dot{0}^{38}$. Taip šiuos îvykius apibūdina amžininkas:

„Turtingi vokiečiai išvažiavo iš Tilžès 8 dienomis anksčiau miesto paèmimo. Landratas ir pašto direktorius išvažiavę jau ciela savaitę anksčiau. Laikraščiai tuo buvo neužgandinti ir landrata su pašto direktoriumi pavadino bobomis $<\ldots>$. Viskas buvo ramu. Gyvenimas tęsiasi kaip paprastai; išẻjo laikraščiai ir liko atnaujintas telegrafiškas susinešimas. " 39

Po Vokietijos 8-osios armijos pergalès prie Mozūrijos ežerų situacija pasikeitė pastarosios naudai ir šiame fronto ruože. Padèti čia esančioms pajėgoms grąžinta 2-oji landvero brigada bei papildomai atsiųsta Karaliaučiaus igulai priklausanti 9-oji landvero brigada, vadovaujama gen. ltn. (?) Klausijaus (Clausius) $^{40}$. Taip pat buvo telkiamos vietos gyventojų jègos. Dar rugpjūčio 20 d. Šilutès apskrityje ịvyko 17-45 metų vyrų šaukimas krašto ginti, jo metu kariuomenę papildè apie 3200 pašauktujųu. Vis dar stokojant karių, rugsẻjo pradžioje buvo papildomai šaukiami ir vyresni nei 45 metų vyrai ${ }^{41}$.

38 Vom ostpreußischen kriegschauplatz. Russischer besuch in Tilsit // Tilsiter algemeine zeitung, 1914 august 26, nr. 199, s. 1 . http://dfg- viewer.de/v1/?set[image]=1\&set[zoom]=default\&se $\mathrm{t}[\mathrm{debug}]=0 \&$ set $[$ double $]=0 \&$ set $[\mathrm{mets}]=\mathrm{http} \% 3 \mathrm{~A} \% 2 \mathrm{~F} \% 2 \mathrm{Fdigital}-\mathrm{b} \cdot$.staatsbibliothek-berlin . de\%2Fdigitalisate\%2Ftilsiter_allgemeine_zeitung\%2Fmets\%2F1914-08-26-8246191.xml

39 Tilžès paėmimas // Rygos garsas, 1914, rugpjūčio 30 (rugsèjo 12), Nr. 59, p. 2.

40 9-ąą landvero brigadą sudarè 24-asis ir 48-asis landvero pėstininkų pulkai. Žr. Die Schlacht bei Tannenberg //http://www.tannenberg1914.de/5_armeen/deutsch.htm

41 J. Sembritzki, Geschichte des kreises Memel, s. 384. 
Rugsėjo pradžioje Rusijos daliniai stovejjo kairiajame Gilijos krante prie Skiepių kaimo (dabar Мостовое, Kaliningrado sritis). Jų veržimąsi turejjo sustabdyti Šilutès apskrities landšturmo kariai. Šiuo tikslu prieš Rusnę buvo įrengti įtvirtinimai, iškasti apkasai. Baiminantis, kad gali nepavykti sulaikyti priešininko, prie Rusnès stovejjo parengti garlaiviai, kurie turejjo išgabenti Vokietijos karius atsitraukimo atveju ${ }^{42}$. Tačiau to neprireikè. Papildomai i ši regioną sutraukti Vokietijos daliniai pradejo staigiai ir sèkmingai stumti priešininką iš šiaurinių Rytų Prūsijos žemių.

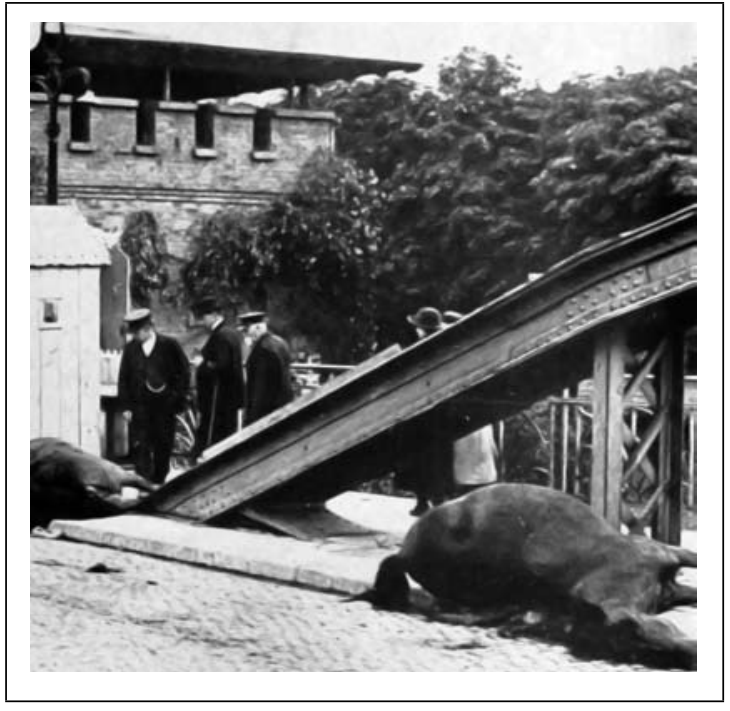

Po Rusijos karių atsitraukimo iš Tilžès ant Karalienès Luizos tilto palikti kritę arkliai. 1914 m. ruduo (VDKM)

Po jau minèto pralaimejjimo prie Mozūrijos ežerų trauktis buvo priversta visa Rusijos 1-oji armija. Dèl greito atsitraukimo ir atskiru daliniu nesusikalbejjimo priešo užnugaryje buvo paliktas 68-osios pėstininkų divizijos 270asis Gatčinos pèstininku pulkas ${ }^{43}$. Rusijos istorikas N. Kersnovskis viename iš savo darbų užsimena, kad visas šis pulkas rugsèjo 13 d. žuvo kautynių prie Tilžès metu ${ }^{44}$. Kai kurie turimi faktai leidžia suabejoti šiuo teiginiu. Vokietijos istorikas J. Zembrickis pamini, kad rugsèjo $11 \mathrm{~d}$. kpt. Arno fon Lenskio (Arno von Lenski) vadovaujami landšturmo daliniai apsupo ir i nelaisvę paėmė apie 5000 priešo karių, kas atitiktų Rusijos pulką ${ }^{45}$. Šie duomenys mums leidžia daryti prielaidą, kad čia ir kalbama apie minėtajj 270-ajj

42 J. Sembritzki, Geschichte des kreises Heydekrug, Memel, s. 280.

43 А. А. Керсеновский, История русской армии, Москва, 1999, с. 507.

44 Ten pat.

45 J. Sembritzki, Geschichte des kreises Heydekrug, Memel, s. 280. 
Gatčinos pèst. pulką, kuris nespejo atsitraukti su visa armija ${ }^{46}$. J. Zembrickio nurodyta data taip pat atrodo įtikinamesnè, kadangi rugsėjo 13 d. kiti Rusijos kariai jau buvo atsitraukę už Nemuno upès.

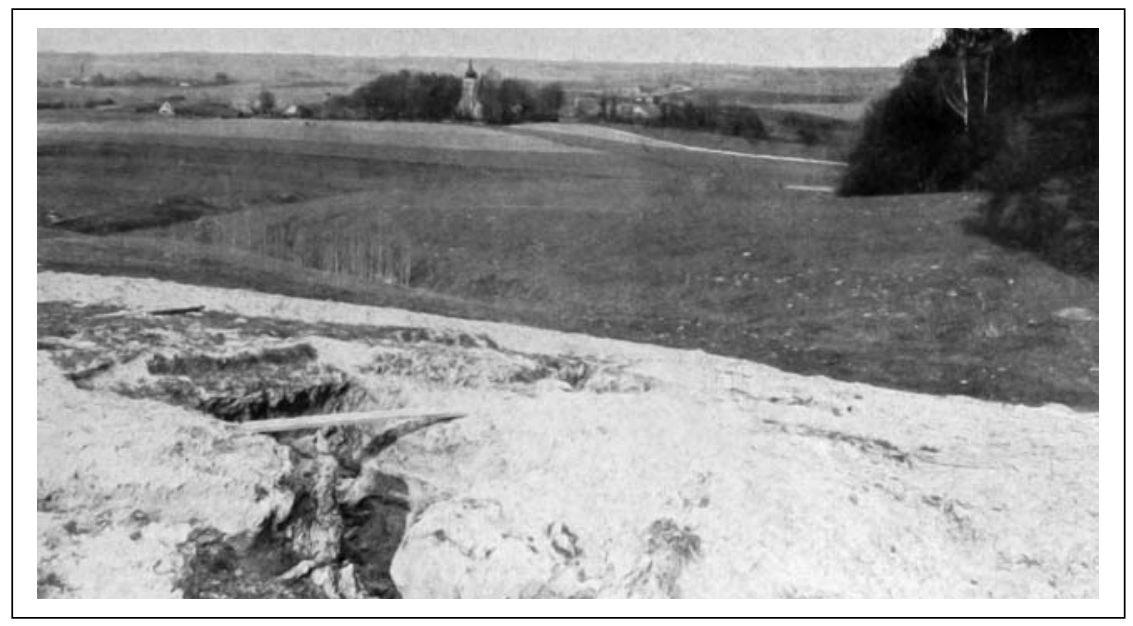

Artilerijos sviedinių sprogimų žymės prie Piktupėnų. 1914 m. ruduo (VDKM)

Rugsèjo $11 \mathrm{~d}$. vakare prasidèjo mūšis dèl Tilžès miesto. 23 val. Rusijos pajègos buvo stipriai Vokietijos artilerijos apšaudytos. Kariaujančių pusių susirèmimas tęsèsi visą naktị iki rugsèjo 12 d. pietų. Rusijos karių padètị dar labiau apsunkino Tilžès gyventojų pasipriešinimas. Prasidèjo gatvių mūšiai. I Rusijos karius buvo šaudoma net pro butų langus. Tad, Vokietijos 9-osios landvero brigados stumiami, jie buvo priversti trauktis tolyn į šiaurę nuo Nemuno ${ }^{47}$. Kapitono (?) Flečerio (Fletcher) vadovaujamas vienas iš 52-ojo lauko artilerijos pulko dalinių pirmasis perejjo per Karalienès Luizos tiltą ị šiaurinị Nemuno krantą ${ }^{48}$.

Tačiau priešininko persekiojimas tuo nesibaigè. Rugsèjo 13 d. Vokietijos pajègos susirèmè su Rusijos kariais prie Šilgalių, kur po mūšio 2-oji landvero brigada ị nelaisvę paėmè apie 1000 belaisvių ir užvaldẻ 10 artilerijos pabū$\mathrm{klų}^{49}$. Vos po kelių dienų, rugsèjo 18-ąją, sèkmingai ì priekį žygiuojanti 9-oji

46 Mūsų prielaidą pagrindžia ir tai, kad pulkas žuvusiu laikomas tada, kai priešininkui atitenka jo vèliava. Tada jo numerio jau nebebūna armijos sąrašuose. Kaip matysime vėliau, 270-asis Gatčinos pést. pulkas dalyvavo ir vėlesniuose šiame regione vykusiuose mūšiuose.

47 Tilžès išgriovimas // Rygos garsas, 1914, rugsėjo 13 (rugsėjo 26), Nr. 73, p. 1.

48 Schlachtfelder in Ostpreussen, s. 153

49 Ten pat. 
landvero brigada užèmė įtvirtintą Rusijos pajègų poziciją prie Piktupėnų ${ }^{50}$. Laikraštyje Viltis užsimenama, kad tą pačią rugsèjo 18 d. apie 11-12 val.

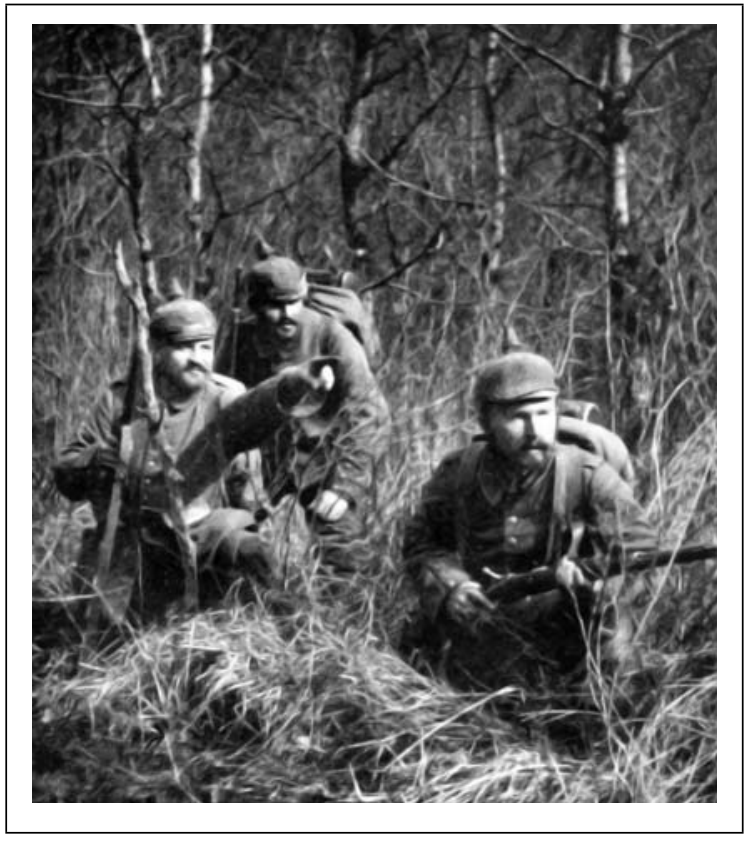

Vokietijos kariuomenès žvalgai. 1914 m. ruduo (VDKM) prie Tauragès, artèdami iš kelių pusių, pasirodè Vokietijos žvalgai. Jie atsargiai žvalgydamiesi ijojo i miestą ir susirado Taurageje gyvenusi Kauno apskrities teismo tardytoją fon Šulcą (von Schultz). Jo buvo paprašyta nurodyti valstybiniu istaigų pastatus. Tardytojas nuvedè karius i muitinę, paštą ir valsčiaus raštinę. Muitineje rastus iš kontrabandininkų atimtus daiktus Vokietijos kariai pasisavino. Pašte suardè telegrafo aparatus. Iki 16 val. vakaro žvalgai paliko miestą. Gyventojai, būgštaudami, kad Vokietijos kariuomenė greitai ateis, pradejo bėgti iš Tauragės. Pasiliko tik apie trečdalis. Gyventojų baimė buvo ne be pagrindo, kadangi rugsèjo $20 \mathrm{~d}$. Tauragè jau buvo užimta Vokietijos 9-osios landvero brigados. Mieste palikta maždaug 2000 kareivių igula. Iš karto apribotos gyventojų išvykimo iš miesto galimybès. Atèjūnai Tauragès miestui skyre 5 tūkst. markių kontribuciją už priešiškas naujai valdžiai kalbas. Per dieną nesumokèjus pinigų buvo pagrasinta sugriauti visą miestą ${ }^{51}$. Tiesa, laikraštyje Rygos garsas galime rasti žinutę apie gerokai didesnę Tauragès miestui skirtos kontribucijos sumą - 80 tūkst. markių, tačiau šis skaičius vargiai tikètinas ${ }^{52}$. Taip pat minima, kad Vokietijos kariai

\footnotetext{
50 Ten pat.

51 Vokiečiai Lietuvoje // Viltis, 1914, gruodžio 10 (23), Nr. 278, p. 2.

52 Europos karas // Rygos garsas, 1914, rugsejo 20 (spalio 3), Nr. 75, p. 3.
} 
iš Tauragès dvaro išsivedė apie 70 arklių, išsivežè visus vežimus, grūdus ir baldus. Buvo plèšiama ir gretimose apylinkèse: Batakiuose, Pagramantyje, Gaurejje. Minimas atvejis, kai Vokietijos karius, plěšiančius Lomių dvarą Batakių parapijoje, tuo metu priklausiusį dvarininkui Henrikui Šulcui, užpuole Rusijos kariai. Po susirèmimo keli Vokietijos kariai buvo užmušti, dèl ko vẻliau keršydami vokiečiai sudegino visą dvarą ${ }^{53}$.

Ilgiau nei mėnesį trukusi Tauragès okupacija baigèsi lapkričio pradžioje. Po sèkmingos Mozūrijos operacijos baigties Vokietijos karinė vadovybé buvo priversta kiek pristabdyti 8-osios armijos puolimą šiaurès rytų kryptimi ir ypatingą dẻmesi sutelkti ị Rusijos pietvakarių frontą. Tai daryti ją vertẻ issipareigojimai Austrijai-Vengrijai ir sunki šios šalies padetis ${ }^{54}$. Savaime suprantama, jog priešininkų jẻgos susilpnejjo ir šiame regione. Pasinaudodama

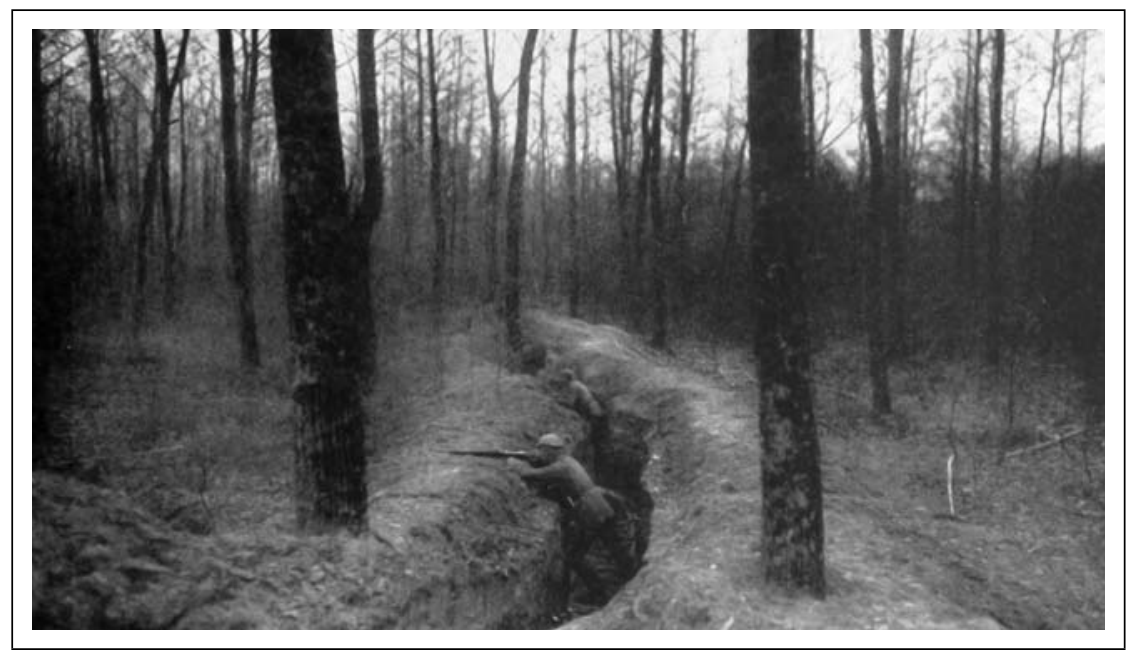

Vokietijos kariai apkasuose. 1914 m. ruduo (VDKM)

tuo, Rusijos kariuomenė pradėjo naują žygi i Rytų Prūsiją iš šiaurès. Apie galimą Rusijos puolimą žinių buvo gauta dar spalio antroje pusejje. Laikraštyje Viltis išspausdintuose ivvykių liudininko atsiminimuose minima, kad spalio $25 \mathrm{~d}$. Vokietijos kariai èmé skubiai rengti ịtvirtinimus, laukdami prie-

53 Nuo Žemaičių iki Paprūsio // Rygos garsas, 1914, spalio 25 (lapkričio 7), Nr. 85, p. 1.

54 M. Pečiulis, Pirmojo pasaulinio karo veiksmai Lietuvos teritorijoje 1915 m. rugpjūčio pabaigoje-rugsėjo ménesị // Karo archyvas, t. XXV, Vilnius, 2010, p. 45. 
šininkų pasirodymo ${ }^{55}$. Gretimų apylinkių vyrai buvo gaudomi ir verčiami statyti ịtvirtinimus ${ }^{56}$. Tačiau tą dieną Rusijos karių nesulaukta. Mūšis dèl Tauragès miesto prasidejo lapkričio $2 \mathrm{~d} .{ }^{57}$ Vokietijos kariai buvo priversti atsitraukti. Taip pat jie buvo išstumti ir iš Lauksargių ${ }^{58}$. Tiesa, antrą kartą nužygiuoti iki pat Tilžès Rusijos kariams pritrūko jègų. Atsitraukdama iš Tauragès, Vokietijos kariuomenè ị nelaisvę paėmė ir kartu išsivedẻ kunigą Fabijoną Kemėši ir tardytoją Šulcą ${ }^{59}$.

Vokietijos kariuomenè neapsiribojo vien tik žygiais šiaurès ir šiaurès rytų kryptimis. Pasitaikė atvejų, kai bandyta pulti ir rytuose, judant dešiniuoju Nemuno krantu. Tiesa, tai labiau buvo panašu į žvalgybinius žygius, stengiantis pasirengti numatomam Kauno tvirtovès puolimui. Net kelis kartus Vokietijos kariai buvo ịžengę ị Jurbarko miestelį. Jo gyventojai nuolat turèjo saugotis ne tik iš artilerijos pabūklų paleistų sviedinių, bet ir plěšikaujančių Vokietijos karių antpuolių ${ }^{60}$. Štai, pavyzdžiui, rugsėjo 28 d. nedidelis, vos apie 100 raitelių, Vokietijos dalinys trumpai buvo užèmęs Jurbarko miestą. Vokietijos kariai apsigyveno kunigaikščio Ilariono Vasilčikovo (Иларион Васильчиков) dvare. To meto laikraštyje rašoma, kad vokiečiai „pareikalavo 250 viedru alaus, konjako ir degtinès. Dvaro tarnus vokiečiai primušé, baugindami sušaudyt ir liepdami pildyti savo paliepimus. Suème taipogi vietinį rusu šventika, kuniga ir rabina, kaipo indèlininkus ir patalpino ị kazematus. Miestely vokiečiai atèmę visus grūdus, valgomuosius daiktus, drabužius ir brangesnius daiktus. Taipogi i kitus parubežio miestelius vokiečiai siuntinejja savo žvalgus, kurie atiminëja nuo žmoniu kas pakliūva, išduodami korteles su parašu: turi užmokèti rusu valdžia"“1.

Likusiais rudens mėnesiais ir žiemos pradžioje šiame fronto ruože tapo kiek ramiau. Tiesa, tiek viena, tiek kita pusè pabandydavo rengti nedidelius žygius ị priešininko teritoriją, tačiau reikšmingų pokyčių, galinčių turèti ịtakos tolesnei karo veiksmų eigai, neivvyko.

\footnotetext{
55 Vokiečiai Lietuvoje // Viltis, 1914, gruodžio 11 (24), Nr. 279, p. 1.

56 Karas Lietuvoje // Lietuvos žinios, 1914, rugsèjo 8, Nr. 163, p. 2.

57 Vokiečiai Lietuvoje // Viltis, 1914, gruodžio 11 (24), Nr. 279, p. 1.

58 Schlachtfelder in Ostpreussen, s. 153

59 Karas Lietuvoje // Lietuvos žinios, 1914, rugsejo 8, Nr. 163, p. 2; P. Čepėnas, Naujujų laiku Lietuvos istorija, t. II, Chicago, 1986, p. 18.

60 Последние из династии Романовых в литовской столице // Россия в красках// http://ricolor.org/europe/litva/lir/ist/romanov/

61 Europos karas // Rygos garsas, 1914, rugsejjo 20 (spalio 3), Nr. 75, p. 3.
} 


\section{KARIAUJANČIŲ ŠALIŲ PLANAI 1915 M. PRADŽIOJE}

1914 m. pabaigoje-1915 m. pradžioje šiaurinèje Rytų fronto dalyje buvo palyginti ramu. Tokia pertrauka buvo labai naudinga nuolat besitraukiančiai iš Rytų Prūsijos ir dalies Lenkijos išstumtai Rusijos kariuomenei, kuriai reikejjo atsigauti po virtinès nesėkmių ${ }^{62}$. Žaibiško karo planai praktiškai jau buvo visiškai sužlugę. Kariaujančios šalys išeikvojo didelę dalį savo išteklių, sukauptų tik trumpiems karo veiksmams vykdyti, tad reikejjo kuo greičiau mobilizuoti pramonę ir parengti naujus planus, kurie padètų iš esmès pakeisti padėti.

1915 m. pradžioje Rusija ėmè kurti naujo grandiozinio puolimo dviem strateginėmis kryptimis planus. Kaip pagrindinè žygio kryptis iš pradžių minètas Berlynas, ị kuri greičiausiai buvo galima patekti užvaldžius Rytprūsius $^{63}$. Tačiau šiai krypčiai formavosi opozicija. Aukščiausioji Rusijos kariné vadovybe turejjo argumentų, kad tiesiausias kelias ị Berlyną - per Vieną, prieš tai eliminavus iš kovos Austrijos-Vengrijos imperiją ${ }^{64}$. Nors Rusijos karinè vadovybè pasirinko abi šias kryptis, nusprendusi pulti plačiu frontu, prioritetas teiktas susidorojimo su Austrijos-Vengrijos imperija planams. Rytų Prūsijos pasienyje esančios Rusijos armijos turejjo surengti tik demonstratyviają akciją. Šiam tikslui metų pradžioje buvo suformuota nauja 12-oji armija, kad pultų Mlavos (dabartinèje Lenkijoje) kryptimi ${ }^{65}$. Jai buvo numatytas pagrindinis vaidmuo. Kad būtų atlaisvintas kelias šiai armijai, šiaurinejje Rytų fronto dalyje esančios 10-oji ir 1-oji Rusijos armijos turejo vẻl žygiuoti ị Rytprūsius - patraukti pagrindinių Vokietijos pajègų dèmesị ir taip priversti jas persigrupuoti. Rusijos vadovybè žinojo, kad Vokietija labai skausmingai žiūri ị Rytprūsių ir jų derlingų žemių okupaciją. Ne veltui Rytų Prūsija dar buvo vadinama Vokietijos aruodu ${ }^{66}$. Operacija turejo prasidèti antroje vasario pusejje.

Vokietija savo ruožtu taip pat puoselejo staigaus ir plataus masto nuo Baltijos jūros iki Karpatų kalnų puolimo planą, kuri iggyvendinusi tikejjosi priversti Rusiją kapituliuoti dar 1915 m. ${ }^{67}$ Vokietijos puolimas Rytų Prūsijoje ir Austrijos-Vengrijos Galicijoje turejo vykti sinchroniškai. Vokietijos

62 M. Pečiulis, Pirmojo pasaulinio karo veiksmai Lietuvos teritorijoje 1915 m. rugpjūčio pabaigoje-rugsejjo ménesi // Karo archyvas, t. XXV, Vilnius, 2010, p. 50.

63 А. Незнамов, Стратегический очерк войны 1914-1918 г. Период с 12 (25) ноября 1914 г. по 15 (28) марта 1915 2., c. 38-39.

64 А. А. Строков, Вооруженные силы и военное искусство в Первой мировой войне, с. 283.

65 А. Незнамов, Стратегический очерк войны 1914-1918 г. Период с 12 (25) ноября 1914 г. по 15 (28) марта 1915 г., с. 59-60.

66 Rytų prūsai ir Vokietija // Lietuvos žinios, 1915, vasario 4 (17), Nr. 14, p. 1.

67 А. М. Зайончковский, Первая мировая война, с. 349. 
karinè vadovybė tikejjosi, kad pagrindinis Rusijos smūgis bus nukreiptas būtent ị Rytų Prūsiją ${ }^{68}$. Tad šiuo tikslu Rytprūsiuose, Nemuno žemupyje tarp Tilžès ir İsručio, ji sutelkè 4 korpusus ${ }^{69}$. Iš šių korpusų buvo suformuota nauja 10 -oji armija ${ }^{70}$. Su šiomis pajègomis ketinta įvykdyti Rusijos 10-osios armijos dvigubo apsupimo planą. Tokius planus buvo galima rengti žinant, kokie silpni yra šios armijos sparnai. Dešiniojo sparno užimta teritorija buvo labai ištęsta ir menkai apsaugota, kairysis sparnas - vis dar neapsaugotas nebaigtos iki galo formuoti 12-osios armijos. Tačiau vis dèlto pagrindinis Vokietijos pajègų smūgis turejo tekti šiaurinei Rytų fronto daliai ir silpnam Rusijos 10-osios armijos dešiniajam sparnui. Jau 1915 m. sausio 28 d. Vokietijos kariuomenès Rytų fronto vadas feldmaršalas Paulius fon Hindenburgas (Paul von Hindenburg) paskelbė direktyvą, kurioje ịsakè 10-osios armijos kairiajam sparnui pulti Vilkaviškio-Tilžès kryptimi ir apsupti dešiniji Rusijos 10-osios armijos sparną. Puolimas turejo prasidèti pirmoje vasario pusejeje ${ }^{71}$. Prireikus jis būtų išplèstas ir šiauriau nuo Nemuno, i Žemaitiją ${ }^{72}$.

\section{MŪŠIAI VOKIETIJOS IR RUSIJOS PASIENYJE 1915 M. PRADŽIOJE}

Pažvelgus ị dešiniji Rusijos 10-osios armijos sparną nebekyla klausimų, kodèl Vokietijos karinè vadovybė numate pagrindinị smūgị suduoti būtent čia. Šiame sparne buvo dislokuotas III armijos korpusas. Tačiau jo saugomos teritorijos prasidejo ị pietus nuo Nemuno žemupio ir tęsėsi iki Darkiemio (dabar Oziorskas, Kaliningrado sritis) ${ }^{73}$. Šiauriau nuo Nemuno - JurbarkoTauragès-Klaipedos linija - einantis fronto ruožas iš Rusijos pusès buvo apsaugotas labai prastai. Šios apie 200 kilometrų besitęsiančios fronto linijos saugumą užtikrinti turèjo jau minètoji 68-osios pèstininkų divizijos 1-oji

68 М. Гофман, Записки и дневники 1914-1918, с. 65.

69 E. Ludendorff, Meine kriegserinnerungen 1914-1918, Berlin, 1919, s. 88.

70 Vokietijos 10-ają armiją sudare XXXVIII ir XXXIX rezerviniai korpusai, XXI armijos korpusas, 16-oji landvero, sustiprinta 1-oji kavalerijos divizijos. Kiek vėliau suformuotas XL rezervinis korpusas. Iš viso armiją sudarė apie 200 tūkst. karių. Rusijos 10-ają armiją metų pradžioje sudare III, XX, XXII, XXVI ir III Sibiro korpusai, iš viso apie 120 tūkst. karių. Žr. M. Pečiulis, Pirmojo pasaulinio karo veiksmai Lietuvos teritorijoje 1915 m. rugpjūčio pabaigoje-rugsejjo mènesi, p. 48.

71 А. Незнамов, Стратегический очерк войны 1914-1918 г. Период с 12 (25) ноября 1914 г. по 15 (28) марта 1915 г., с. 65.

72 И. И. Ростунов, Русский фронт Первой мировой войны, с. 210.

73 А. М. Зайончковский, Первая мировая война, с. 349. 
brigada, 269-asis Novorževo ir 270-asis Gatčinos pèstininkų pulkai ${ }^{74}$. Formaliai 68-ajai pėstininkų divizijai dar priklause ir 271-asis Krasnoselsko bei 272-asis Gdovo pulkai, kurie sudare 2-ąą brigadą ${ }^{75}$. Tačiau gali būti, kad pastaroji brigada nuo pat karo pradžios buvo įtraukta į 10-osios Rusijos armijos III Sibiro korpuso sudėtị, kadangi 1915 m. metų pradžioje ją mes matome būtent šio korpuso sąrašuose ${ }^{76}$.

Vokietijos pajègos šiame fronto ruože taip pat nebuvo gausios. Jas sudare daugiausia landvero ir landšturmo daliniai ${ }^{77}$. Tačiau tai dar nieko nereiškè. Kaip jau minèta, išplètotas Vokietijos geležinkelių tinklas labai padidino kariuomenès mobilumą. Iškilus pavojui ji galèjo permesti pajègas i pavojingiausius rajonus.

Nors ir buvo keletas smulkių pasienio susirèmimų, situacija liko beveik tokia pat. Tiesa, padètis pamažu pradejo keistis. Minima, kad visą sausio 26 d. vyko susirèmimai Tilžès apylinkèse. Rusijos pajëgos neteko 10 karių, dar 3 buvo sužeisti ${ }^{78}$. Sausio 31 d. apie 30 Rusijos karių grupe, atlikdama žvalgybą, perẻjo sieną prie Kretingalès, tačiau, susitikusi su Vokietijos kariais, po susišaudymo buvo priversta grižti atgal už valstybès sienos ribų ${ }^{79}$. Tą pačią dieną apie 12 val. dienos virš Jurbarko praskrido vokiečių lëktuvas ir ant miesto numetė dvi bombas. Viena iš jų nukrito prie žydų sinagogos ir apgadino netoli buvusius pastatus, tačiau nè vieno gyventojo nesužeidè ${ }^{80}$. Tai buvo ne paskutinis kartas, kai jurbarkiečiai turejjo kęsti lèktuvų antskrydžius. Štai laikraštyje Lietuvos žinios minima, kad sausio 28 d. (pagal naujaji kalendorių - vasario 13 d.) virš Jurbarko miesto skrendantis vokiečių lèktuvas mèté ,plienines vylyčias ${ }^{\text {“81. }}$.

74 Taikos metu Rusijos pèstininkų pulką sudarè apie 5000 karių, tačiau prasidèjus karui mažai liko tokio dydžio pulkų. Pasitaikè atvejų, kai pulkai buvo sukomplektuoti tik $50 \%$. Žr. А. А. Строков, Вооруженные силы и военное искусство в Первой мировой войне, с. 142; И. И. Ростунов, Русский фронт Первой мировой войны, Москва: Наука, 1976, с. 209.

75 К. А. Залесский. Первая мировая война. Правители и военоначальники, с. 496; О. Леонов, И. Ульянов Регулярная пехота 1855-1918, с. 267; War Chronicle. War Journal. Soldiers, letters, pictures of the war, p. 3.

76 Российская императорская армия в Великую войну // http://www.ryadovoy.ru/forum/ index.php?topic $=1275.0$

77 Schlachtfelder in Ostpreussen, s. 153.

78 KAA, f. 50, ap. 2, b. 199, 1. 10.

79 Ten pat 1. 22.

80 Ten pat, 1. 26.

81 Sen. „vylyčios“ - plieninès strèlès smailiais galais. Jos buvo saugomos lèktuve esančioje dèžèje. Lèktuvui skrendant virš priešo dalinių dislokavimo vietos šios strèlès, atidarius dèžès dugną, buvo metamos žemyn. Vienoje děžèje galëjo būti 1000 ir daugiau tokių strèlių. Jos specialiai buvo pagamintos taip, kad krisdamos pasisuktų smaigaliu žemyn. Dèl ịgto pagreičio 
Laikui bėgant Rusijos kariuomenès žvalgų reidai ị priešininko teritoriją darėsi dažnesni. Dar vienas žvalgų susidūrimas įvyko prie Kretingos vasario 2 d. Rotmistro (?) Smilnovo (Смилбнов) vadovaujamas 30 Rusijos žvalgų būrys buvo priverstas atsitraukti, palikęs mūšio lauke 2 sužeistus karius ${ }^{82}$. Tačiau ši aktyvi žvalgyba Kretingos, Gargždų apylinkèse vyko ne veltui. Jau vasario 8 d. Rusijos kariai surengè puolimą nuo Gargždų pusės link Grambaviškių kaimo (dabar Klaipedos r.). Jis prasidèjo apie 11 val. dienos. Puolime dalyvavo viena 5-ojo kavalerijos Gargždų pasienio apsaugos pulko šimtinè, 37-oji ir 40-oji pašauktinių rinktinès (rus. „дружинь ““) Prie Grambaviškių kaimo ịsitvirtinę Vokietijos kariai iš artilerijos pabūklų i puolančiuosius paleido ugnị, taip pat pradejo apšaudyti Gargždų miestelį. Saltinyje minima, kad apšaudymas tęsèsi iki 17 val., iš viso buvo paleista 60 šūvių, o Rusijos kariai turèjo atsitraukti, nepralaužę priešininko gynybos $^{84}$. Taip pat užsimenama apie kautynes i vakarus nuo Jurbarko vasario pradžioje ${ }^{85}$. Šią informaciją patvirtina ir Vokietijos pusè. Minima, kad vasario 10 d. prie Kazikènų kaimo (dabar Jurbarko r.) pastebètos Rusijos pajëgos, prilygstančios vienam batalionui. Ivvykus susirèmimui, Rusijos kariai buvo priversti atsitraukti ${ }^{86}$. İdomus atvejis užfiksuotas archyviniuose šaltiniuose. Vasario 13 d. Kauno gubernatoriaus pranešime Daugpilio karinès apskrities viršininkui rašoma, kad po susirėmimų tarp Tilžès ir Viešvilès buvo sužeistas pulkininkas Petras Vrangelis (Пётр Вра́нгель), jis vèliau tapo vienu iš Rusijos pilietinio karo vadų ${ }^{87}$.

Kad situacija šiame fronto ruože darèsi vis įtemptesnè, liudija ir Kauno gubernijos gyventojų teisių suvaržymas. Kauno gubernatoriaus ir Daugpilio karinès apskrities viršininko įsakymu buvo uždrausta bet kokia korespondencija žydų vartojama kalba. Tokius laiškus liepta iš karto naikinti ${ }^{88}$. Iš Jurbarko miestelio kaip nepatikimus asmenis pradèta iškeldinti liuteronų konfesinei

krentanti strèlè galejjo perdurti išilgai stovintị žmogų. Skrendant lèktuvu jos buvo paskleidžiamos ganètinai plačiai. Žr. Prancūzų lakstytojų vyličios // Lietuvos žinios, 1915, kovo 11(24), Nr. 29, p. 3; Vokiečių aeroplanai Jurbarke // Lietuvos žinios, 1915, vasario 1 (14), Nr. 13, p. 4.

82 KAA, f. 50, ap. 2, b. 199, 1. 29-30.

83 Pašauktinių rinktinè - karinis junginys, sudarytas iš maždaug 1000 karių, tačiau karo metu šis skaičius galejjo būti gerokai mažesnis. Žr. Советская военная енциклопедия, t. 3, Москва, 1977 г. с. 265.

84 KAA, f. 50, ap. 2, b. 199, 1. 43.

85 Karo apžvalga // Lietuvos žinios, 1915, vasario 6 (19), Nr. 14, p. 1.

86 Schlachtfelder in Ostpreussen, s. 153.

87 KAA, f. 50, ap. 2, b. 199, 1. 49.

88 Lietuvos žinios // Lietuvos žinios, 1915, vasario 25 (kovo 10), Nr. 23, p. 2. 
bendruomenei priklausančius žmones ${ }^{89}$. Bijant galimo vokiečių puolimo ypatingų saugumo taisykliu įsakyta laikytis Kauno-Liepojos geležinkelio linija kursuojančiuose traukiniuose: „Liepojos-Romnu geležinkelio valdybos paskelbta toks įsakymas. Traukiniui važiuojant tarp stočiu Kèdainiai-Žeimiai, Jonava-Gaižūnai, Luša-Venta ir Grobin-Pleikè, turi būti uždarytos durys, langai, išeinamosios vietos ir tuo laiku niekas negali stovèti priešduryje. "90

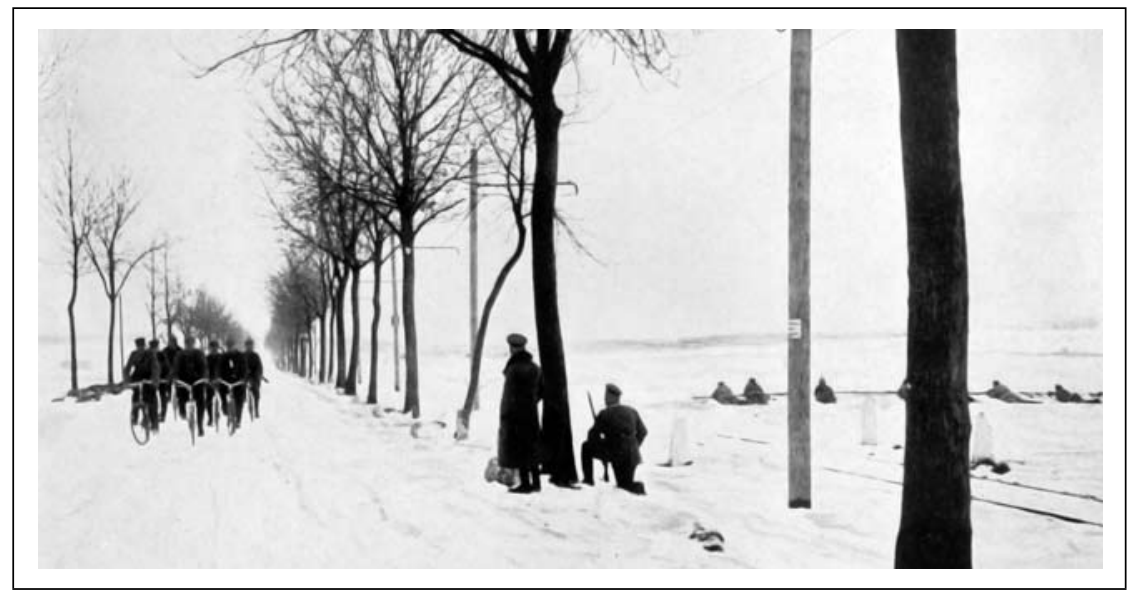

Vokietijos kariuomenès dviratininkai grịžta ị Tilžę. 1915 m. žiema (VDKM)

1915 m. vasario viduryje ilgai kaupęsis karo debesis pratrūko. Vokietijos ir Rusijos pasienyje Žemaitijos prieigos vèl tapo įnirtingų mūšių lauku. Vokietijos karinè vadovybė nusprende galutinai išstumti Rusijos karius iš šiaurinių Rytų Prūsijos žemių. Šią užduotị igyvendinti buvo pavesta Karaliaučiaus guber-natoriui kavalerijos gen. Giunteriui fon Papricui (Günther von Pappritz $)^{91}$. Jo žinion buvo perduotos visos Karaliaučius landšturmo pajègos, taip pat nedidelis skaičius artilerijos pabūklų ${ }^{92}$. Vokietijos kariuomenès grupè, kurios pagrindą sudarė rezervinè Tilžès brigada, vadovaujama gen. mjr. (?) fon Ezebeko (von Esebeck) remiama vietinių landšturmo dalinių, vasario mėnesi pradèjo savo žygị nuo Tilžès pusès ir palyginti greitai

\footnotetext{
89 Lietuvos žinios // Lietuvos žinios, 1915, vasario 8 (21), Nr. 16, p. 2.

90 Ivairios žinios // Lietuvos žinios, 1915, vasario 13 (26), Nr. 18, p. 4.

91 М. Гофман, Записки и дневники 1914-1918, с. 71.

92 E. Ludendorff, Meine kriegserinnerungen 1914-1918, Berlin, 1919, s. 104 // http://www.archive.org/stream/meinekriegserinn00lude
} 
įsitvirtino fronto ruože nuo pat Jurbarko iki Nemirsetos ${ }^{93}$.

Kad pristabdytų i priekị žengiančius Vokietijos karius, buvo pasiųstos 3 pašauktinių rinktinès iš Tauragés ${ }^{94}$. Tačiau Rusijos kariai nesugebejjo deramai pasipriešinti gausesniam priešininkui ir buvo priversti greitai atsitraukti atgal ị Tauragę, palikę mūšio lauke 3 artilerijos pabūklus su amunicija. Ivykiams klostantis tokia linkme, imta vis garsiau kalbèti apie numatomą tolesnị traukimąsi užleidžiant priešininkui ne tik pasienio kaimus, bet ir Tauragę. Jau vasario $12 \mathrm{~d}$. iš miesto išvažiavo gurguolès, pradètos evakuoti valdžios îstaigos ${ }^{95}$. Tauragès gyventojai, prisimindami ankstesni vokiečiu „šeimininkavimą“ mieste, priešui dar tik artejjant, ėmė bėgti iš miesto, taip gelbẻdamiesi nuo galimo pléšikavimo bei turto rekvizavimo ${ }^{96}$.

Sparčiai i prieki žygiuojantys Vokietijos kariai vasario 14 d. užėmé Piktupénus, vasario 16 d. - Lauksargius, o 18 d. - Tauragę (jau antrą kartą per šị karą). Mūšių metu buvo sudeginti Tauragès priemiesčiai, artilerijos sviedinių sprogimų apgadinta Tauragès bažnyčia, muitinès sandèlis ir karinè ligoniné $\dot{~}^{97}$. Pavieniai daliniai pasiekè ir sudegino Skaudvilès kaimą ${ }^{98}$. Vokietijos kariai, vos tik užèmę miestą, pradèjo ruoštis galimam priešininko sugrịžimui. Prieš Tauragę nuo Skaudvilès pusès buvo pradėti kasti apkasai, jie nusitęsè abiejose kelio Tilžè-Tauragé pusèse ${ }^{99}$.

\section{KOVOS DE்L KLAIPE்DOS IR TAURAGE்S}

Ši Rusijos pajègų nesėkmè, savaime suprantama, sulaukè neigiamo atgarsio Petrograde. Vokietijos kariuomenès įsiveržimas ị krašto gilumą buvo labai pavojingas Rusijos 10-ajai armijai, vasario antroje puseje patyrusiai skaudų pralaimèjimą Augustavo miškuose ${ }^{100}$. Siekiant išvengti apsupimo, nuspręsta stiprinti regione esančias pajègas. Kita vertus, tai buvo savotiškas bandymas reabilituotis po visos virtinès nesėkmių. Nepavykus puolimui piečiau nuo Nemuno žemupio esančiame fronto ruože, tikètasi, kad gal pa-

\footnotetext{
93 Friedrich Immanuel. Der Krieg im Herbst und Winter im Osten. Der deutsche Landkrieg, Erster Teil:Vom Kriegsbeginn bis zum Frühjahr 1915 // Der Weltkampf um ehre und recht.

94 KAA, f. 50, ap. 2, b. 199, 1. 51.

95 Ten pat, 1. 53, 58.

96 Iš Lietuvos // Rygos garsas, 1915, kovo 3 (16), Nr. 25, p. 3.

97 KAA, f. 50, ap. 2, b. 199, 1. 69, 74, 81; Schlachtfelder in Ostpreussen, s. 154.

98 KAA, f. 50, ap. 2, b. 199, 1. 103.

99 Ten pat, l. 103.

${ }^{100}$ Plačiau apie tai žr. Esče, 10-os rusų armijos XX korpuso veiksmai Rytų Prūsijoje (1915 m. vasario 9-21 d.) // Mūsų žinynas, t. 1, Nr. 3, 1921.
} 
vyks pralaužti frontą būtent ties Tilže ir Klaipėda ${ }^{101}$. Tilžès kryptis Rusijos kariuomenei jau buvo „pažįstama“. Čia bandyta prasiveržti ir 1914 m. karo veiksmų metu, tačiau nesėkmingai. Klaipėda liko visų šių, daugiau nei pusę metų besitęsiančių, kovų nuošalyje. XX a. pradžioje ji buvo vienas iš svarbiausių Rytų Prūsijos miestų, regioninès reikšmès uostas, daugiausiai orientuotas i prekių tiekimą Rusijai. Iki Pirmojo pasaulinio karo čia gyveno apie 20 tūkst. gyventojų. Pusę metų miestiečiai galèjo gyventi palyginti ramiai. Tačiau dabar situacija turèjo pasikeisti.

Vokietijos karinè vadovybè turèjo informacijos apie priešininko pajëgų telkimą šiame fronto ruože, tačiau neskyrè tam daugiau dèmesio, kadangi tokių pranešimų gaudavo dešimtimis kiekvieną dieną, tad ir šias žinias apie puolimą galëjo palaikyti melagingomis ${ }^{102}$. Be to, Rusijos 10-oji armija ką tik buvo pralaimejjusi prie Augustavo, kur prarado praktiškai visą XX korpusą, tad gali būti, jog Vokietijos karinè vadovybé nesitikejjo, kad Rusija eikvos tokias brangias jėgas puldama, atrodytų, visai nereikšmingame fronto ruože, ị kurị net nebuvo nutiesusi geležinkelių, kad galètų vežti savo kariuomenę.

Rengiantis naujam puolimui Žemaitijoje ir Kurše buvo suformuota vadinamoji „Rygos-Šiauliu grupé“. Nors ir ịvardytas kaip vienas darinys, šis dalinys buvo sudarytas iš dviejų atskirų grupių, kurios turëjo skirtingas puolimo užduotis. Kurše suformuotas dalinys rengèsi žygiui į Klaipėdą, o Žemaitijoje sutelkti kariai - pulti Tauragès-Tilžès kryptimi. Pastarosios grupès, vadovaujamos gen. mjr. A. Apuchtino, pagrindą sudare 269 -asis Novorževo ir 270-asis Gatčinos pulkai, turintys 20 artilerijos pabūklų. Šią grupę dar sustiprino 6 pasienio pèstininkų ir 6 pasienio kavalerijos šimtinès, taip pat 5 ypatingosios Orenburgo kazokų šimtinès ${ }^{103}$. Iš viso link Tauragès žygiuojančią Rusijos kariuomenès grupę sudarẻ apie 10 tūkst. karių. O Tauragès miestą turejo ginti tik 14 landšturmo kuopų ${ }^{104}$. Taigi akivaizdų kiekybini pranašumą turejo Rusija, kadangi, pačiais optimistiškiausiais skaičiavimais, Vokietijos pajègas galëjo sudaryti ne daugiau kaip 3,5 tūkst. karių ${ }^{105}$.

${ }^{101}$ War Chronicle. War Journal. Soldiers, letters, pictures of the war, p. 3.

102 М. Гофман, Война упущенных возможностей, с. 77-78.

${ }^{103}$ Friedrich Immanuel. Der Krieg im Herbst und Winter im Osten. Der deutsche Landkrieg, Erster Teil: Vom Kriegsbeginn bis zum Frühjahr 1915 // Der Weltkampf um ehre und recht; А. Незнамов, Стратегический очерк войны 1914-1918 г. Период с 12 (25) ноября 1914 г. no 15 (28) марта 1915 г., c. 61.

${ }^{104}$ War Chronicle. War Journal. Soldiers, letters, pictures of the war, p. 1.

${ }^{105}$ Karo pradžioje Vokietijos karių kuopą sudare 250 karių. Savaime suprantama, karo metu šie skaičiai kito - dažniausiai mažèjo. Kartais, ypač po didesnių mūšių, dalinį sudarydavo daugiau nei trigubai mažiau karių nei buvo numatyta karo pradžioje. Žr. А. А. Строков, Вооруженные силы и военное искусство в Первой мировой войне, с. 143. 
Pavieniai susirėmimai prie Tauragès vyko jau nuo kovo pradžios. Kovo 6 d. prasidejo miesto apšaudymas iš artilerijos pabūklų, o vẻliau ịvyko karių susirèmimas. Jo metu buvo sužeista 70 Rusijos karių ${ }^{106}$. Tačiau i pagrindinius mūšius dèl Tauragès gen. mjr. A. Apuchtino daliniai stojo kovo 16 d. Miestą šturmuoti planuota dviem kryptimis. 270-asis Gatčinos pulkas turèjo apeiti Tauragę iš dešinès pusės, kad patektų i priešininkų užnugarị ir atkirstų jų atsitraukimo kelius. 269-asis Novorževo pulkas puolè tiesiai, laikydamasis Tauragès-Šiaulių kelio linijos ${ }^{107}$. Tokiu būdu miestas greitai buvo apsuptas iš trijų pusių ${ }^{108}$. Priartejęs prie Tauragès, 269-asis Novorževo pulkas susidūrè su stipriu Vokietijos pajègų pasipriešinimu. Rusijos kariai turèjo pralaužti îtvirtintus ruožus, saugomus spygliuotos vielos pynių ir dengiamus priešininkų kulkosvaidžių. Jų puolimą palaikė dviejų 68-osios artilerijos brigados baterijų pabūklai ${ }^{109}$. Kaktomuša puldami ịsitvirtinusias, nors ir negausias, priešininko pajėgas, Rusijos kariai patyrẻ daug nuostolių. Pirmieji puolimą pradeję 3-iasis ir 4-asis 269-ojo Novorževo pulko batalionai neteko savo vadų. 3-iojo bataliono vadas kpt. (?) Zateplinskis (Затеплинский) žuvo, o 4-ojo bataliono kpt. (?) Pitka (Питка) buvo sunkiai sužeistas ${ }^{110}$. Vietoje jų vadovavimą perèmę kuopų vadai bandẻ tęsti puolimą, tačiau pralaužti priešininkų įtvirtinimų nepavyko. Tam įtakos turejjo ir tai, kad nebuvo sunkiosios artilerijos. Turimi artilerijos pabūklai negalejo efektyviai palaikyti puolančių péstininkų ir išardyti įsitvirtinusių Vokietijos karių pozicijų ${ }^{111}$. Nepavykus atakai, Novorževo pulkas turejjo atsitraukti ị tas pačias pozicijas, iš kurių pajudëjo. Archyviniuose šaltiniuose minima, kad tą dieną buvo sužeisti 8 karininkai ir 148 Rusijos kariuomenès kariai ${ }^{112}$.

Kovo 17 ir 18 dienomis situacija liko praktiškai nepakitusi ${ }^{113}$. Kovo 19 d. Tauragès puolimas prasidejo iš naujo. Tačiau ši kartą Rusijos kariams sekèsi daug geriau. Mieste esančios Vokietijos pajègos, bijodamos, kad nebūtur visiškai apsuptos iš 270-ojo Gatčinos pulko pusès, pradèjo trauktis. Landšturmo kuopoms pavyko jèga prasiveržti pro jas supančius Rusijos dalinius ir atsitraukti iki Lauksargių. Tiesa, vis dèlto viena landšturmo kuopa, vado-

\footnotetext{
${ }^{106}$ KAA, f. 50, ap. 2, b. 199, 1. 152, 155.

${ }^{107}$ С. Бирюк, 68-я пех. дивизия в Первой мировой войне // Рейтар, но. 40, 2008 // http://1914.borda.ru/?1-2-20-00000273-000-80-0

108 KAA, f. 50, ap. 2, b. 199, 1. 199-200.

${ }^{109}$ С. Бирюк, 68-я пех. дивизия в Первой мировой войне // Рейтар.

${ }^{110}$ Ten pat.

111 Ten pat.

112 KAA, f. 50, ap. 2, b. 199, 1. 199-201.

${ }^{113}$ Ten pat, 1. 206, 219.
} 
vaujama grafo (?) fon Hageno (von Hagen), įsitvirtinusi kairiajame gynybos sparne, pateko ị apsuptị, tačiau sugebejo ne tik iš jos išsiveržti, bet dar ir paimti ị nelaisvę 50 Rusijos karių ${ }^{114}$.

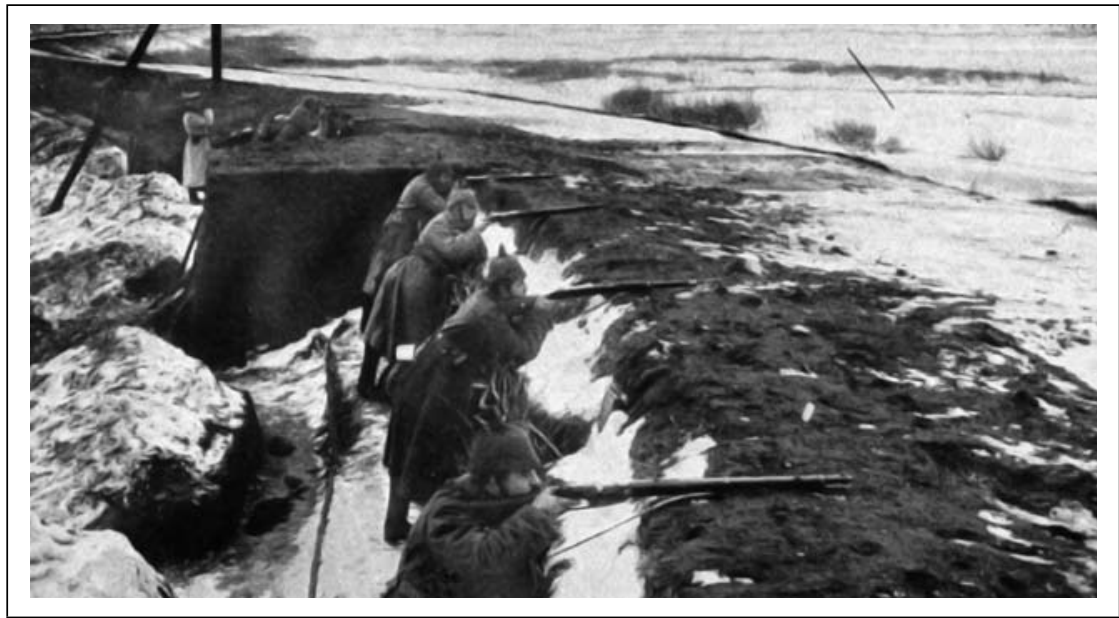

Kaip gynybiniai įtvirtinimai Vokietijos kariams pasitarnavo ir Nemuno pylimai, pastatyti siekiant apsisaugoti nuo pavasario potvynių.

915 m. žiemos pabaiga-pavasario pradžia (VDKM)

Užėmus Tauragę, Rusijos pajègų puolimas nesibaigè. Toliau buvo puolama Tilžès link. To meto spauda mini, kad tą pačią kovo 19 d. Rusijos kariuomenè, žygiavusi pirmyn nuo Tauragès, išstūmè Vokietijos karius ir iš Lauksargių. Tačiau archyvinè medžiaga ši teigini paneigia. Minima, kad prie Lauksargių vẻl susidurta su labai aktyviu Vokietijos karių pasipriešinimu. Puolimo metu i nelaisvę buvo paimti 35 vokiečių kariai, užgrobtas ginklų ir inžinerijos prietaisų sandèlis. Per kovo 18 ir 19 dienų mūšius Tauragès apylinkèse buvo sužeista apie 200 Rusijos karių ${ }^{115}$.

Kaip jau minèta, naujas puolimas ị Rytų Prūsiją vyko dviem kryptimis. Tuo metu, kai 269-asis Novorževo ir 270-asis Gatčinos pulkai puolè Tauragę, kita Rusijos karių grupė pradèjo žygi ị Klaipėdą. Jai vadovauti buvo paskirtas gen. mjr. Aleksejus Potapovas (Алексей Потапов). Ši naują dalinị sudarẻ 7 péstininkų batalionai, 1 kavalerijos eskadronas, 2 jūrų pèstininkų kuopos, Rygos ir Liepojos pasienio apsaugos daliniai, 270-ojo Gatči-

${ }^{114}$ War Chronicle. War Journal. Soldiers, letters, pictures of the war, p. 3.

${ }^{115}$ KAA, f. 50, ap. 2, b. 199, 1. 219. 
nos pulko 1 batalionas. Klaipėdos puolimo grupe buvo sustiprinta 8 senais artilerijos pabūklais ${ }^{116}$. Dèl autentiškos informacijos stokos sunku pasakyti tikslų Rusijos pajègas sudariusių karių skaičių. Istoriografijoje ir turimuose šaltiniuose skaičiai labai ịvairuoja - nuo 4000 iki 11000 karių. Vis dèlto labiausiai tikètina paskutinè versija. Ši skaičių galime rasti ịvykių amžininko J. Zembrickio veikale ${ }^{117}$. Jis patvirtina faktą, kad Rusijos puolimas vyko dviem kryptimis - pro Nemirsetą ir Laugalius. Pro Nemirsetą žygiavo 8000 karių grupè, o pro Laugalius $-3000^{118}$. Būtent tai, kad puolimas vyko dviem kryptimis, tikriausiai ir klaidino kitus autorius nusakant tik vienos puolančiosios grupès karių skaičių, kartu visai užmirštant kitą jų grupę.

Klaipedai pulti buvo sudarytas iš pirmo žvilgsnio ganètinai stiprus karinis junginys, tačiau istoriografijoje šios Rusijos pajègos ir jos kovinis pasirengimas vertinama labai skeptiškai. Visų pirma jau iš karto matyti, kad tai buvo tikras pėstininkų, kavalerijos, pasienio apsaugos ir jūrų pèstininkų dalinių, staiga surinktų konkrečiai operacijai vykdyti, kratinys. Nagrinėdami Rusijos autorių darbus galime rasti informacijos, kad minètus laivyno dalinius daugiausiai sudare iš laivų už icvairius nusižengimus pašalinti kariai ${ }^{119}$. Ne visai aišku, kokio stiprumo pajègos buvo paliktos ginti Klaipėdos miesto. To meto lietuviškoje spaudoje minima, kad Rusijos kariai susikovè su dviem landšturmo pulkais ${ }^{120}$. Tačiau šis skaičius akivaizdžiai padidintas, kadangi tokiu atveju Vokietijos pajëgos kiekybiškai būtų beveik prilygusios Rusijos ${ }^{121}$. Tiek Vokietijos, tiek Rusijos autoriai mini kelias landšturmo kuopas arba šiaip silpnas pajègas, kurioms vadovavo kpt. (?) Krauzè (Krause) ${ }^{122}$. Vienoje istoriografineje pozicijoje nurodyta 800 karių $^{123}$. Vis dèlto peršasi išvada, kad Klaipedoje palikta ịgula buvo gerokai mažesnè ir už Tauragę ginančių karių pajègas, kadangi per visas iki tol vykusias Pirmojo pasaulinio karo kovas šiame fronto ruože vyko tik nedideli pasienio susirèmimai. Dèl šios priežasties Vokietijos karinei vadovybei paprasčiausiai buvo netikslinga laikyti didelę

\footnotetext{
${ }^{116}$ Klaipėdos iszgascziu dienos // Lietuwiszka ceitunga, 1915 kovo 30, Nr. 34, p. 1.

${ }^{117}$ J. Sembritzki, Geschichte des kreises Memel, s. 389-390.

${ }^{118}$ Ten pat.

${ }^{119}$ А. Адылов, Третий штурм.

${ }^{120}$ Kaip paėmė Klaipėdą. Rytų karo lauke. Karas // Lietuvos žinios, 1915 kovo 11 (24), Nr. 29, p. 3.

${ }^{121}$ Vokietijos kariuomenès pulką karo pradžioje sudarè 3100 karių. Žr. А. А. Строков, Вооруженные силы и военное искусство в Первой мировой войне, с. 143.
}

${ }^{122}$ А. Адылов. Третий штурм; Friedrich Immanuel. Der Krieg im Herbst und Winter im Osten. Der deutsche Landkrieg, Erster Teil: Vom Kriegsbeginn bis zum Frühjahr 1915 // Der Weltkampf um ehre und recht; J. Sembritzki, Geschichte des kreises Heydekrug, Memel, 1920, s. 287.

${ }^{123}$ Schlachtfelder in Ostpreussen, s. 154. 
igulą. Be to, apie negausias Klaipedos gynejų gretas iš žvalgybos patikimų duomenų buvo gavusi operaciją planuojanti Rusijos kariné vadovybe $\dot{e}^{124}$.

Puolimas prasidejo ankstyvą kovo $17 \mathrm{~d}$. rytą. Apie 5 val. siaučiant pūgai 8000 Rusijos karių grupé peržengè sieną ties Nemirseta ${ }^{125}$. Kita Rusijos kariuomenès grupe lūkuriavo prie sienos ties Laugaliais. 6 val. ryto prasidejjo Vokietijos pozicijų prie Grambaviškių kaimo apšaudymas iš artilerijos pabūklų ${ }^{126}$. Iš karto po to vyko Rusijos kariuomenès ataka. Rusijos kariai sutiko vokiečių landšturmo pasipriešinimą, tačiau gausesnès jų pajėgos įveike Vokietijos karius - privertė juos atsitraukti iki Klausmylių-Mišeikių kaimų linijos. Dèl skuboto atsitraukimo priešininkui buvo palikti 2 artilerijos pabūklai, 4 kulkosvaidžiai, 2 sunkvežimiai, prikrauti amunicijos, taip pat kitų įvairių priemonių ${ }^{127}$. Rusija puolimo metu neteko 2 karių, dar 20 buvo sužeista ${ }^{128}$. Visa tai tik patvirtina faktą, kad Vokietija nesitikejo staigaus Rusijos puolimo būtent šioje fronto vietoje: „Kai Rusijos kariuomené perëjo siena ties Gargždais, Vokietija greičiausiai visai nesitikejo užpuolimo, vietos gyventojai nebuvo galvoje apie išsikèlima gyventi kur nors kitur. Tik tada, kai Rusijos kariuomene pradejo vyti sumuštus Vokietijos karius $i$ Klaipéda, tik tada kilo tarp gyventoju didelis samyšis. Vietos gyventojai taip buvo ìsitikejje i vokiečiu nepergalejima, kad net Klaipèda paèmus, netikèdami, kraipé galva ir saké, kad ilgai taip nepaliks. “"129

Žygiuodami ị Klaipèdą Rusijos kariai degino pakeliui esančias sodybas ir kaimus. Minima, kad iš viso buvo sudeginta apie penkiolika gyvenviečių. Smarkiai nukentejo vietos gyventojai. Nemažai jų buvo sužeista ir užmušta ${ }^{130}$. Gali būti, kad toks Rusijos karių elgesys sutelkè vietos gyventojus kovai su žiauriu priešininku. Klaipėdos puolime dalyvavę Rusijos kariai pasakojo: „Kad Prūsijos gyventojai padeda savo kariuomenei, tai jau žinoma, bet šį karta vietiniu gyventoju pasipriešinimas buvo dar didesnis, negu reguliariškosios vokiečiu armijos. “131

Stokojant karių, i miesto gynybą buvo ịtraukti ir vietos gyventojai. Vokietijai aprūpinimo amunicija ir ginkluote problema nebuvo tokia aktuali kaip Rusijai, tad priemonių gintis nuo priešo pakako ir civiliams. Jie

${ }^{124}$ Martha Pascherat, Der Russeneinfall im ersten Weltkrieg // http://www.memelland-adm.de/ Archiv/20\%20Berichte/Russeneinfall.html

125 Schlachtfelder in Ostpreussen, s. 154.

${ }^{126}$ KAA, f. 50, ap. 2, b. 199, 1. 207.

${ }^{127}$ KAA, f. 50, ap. 2, b. 199, 1. 207; Rytų frontas. Europos karas // Rygos garsas, 1915 kovo 7 (20), Nr. 27, p. 3; Rytų frontas. Europos karas // Rygos garsas, 1915 kovo 10 (23), Nr. 28, p. 3.

${ }^{128}$ KAA, f. 50, ap. 2, b. 199, 1. 207.

${ }^{129}$ Klaipedos paėmimas ir atidavimas. Karo vaizdai // Rygos garsas, 1915 kovo 14 (27), Nr. 30, p. 1.

${ }^{130}$ Der russische Raubzug gegen Memel.

${ }^{131}$ Klaipedos paėmimas ir atidavimas. Karo vaizdai // Rygos garsas, 1915 kovo 14 (27), Nr. 30, p. 1. 
buvo apginkluoti ne tik paprastais šautuvais, bet ir rankinėmis granatomis, kulkosvaidžiais. Vienoje vietoje Rusijos kariai netgi perėmé gyventoju paliktą nedidelio kalibro patranką ${ }^{132}$. Nors, kaip jau minèta, Rusijos puolimas Vokietijai buvo netiketas, negalime visiškai nuvertinti jos pasirengimo atremti priešininką. Vis dèlto vyko karas, todẻl vokiečiai šiam tikslui rengè įtvirtinimus. Žygiuodami link Klaipėdos Rusijos kariai matė kas 3-5 $\mathrm{km}$ žvalgams pastatytus teritorijos stebejjimo bokštelius. İvairūs mūriniai pastatai taip pat naudoti kaip atramos punktai. Iš jų vietos gyventojai ir kariai galejo netikètai puldinėti žygiuojančią Rusijos kariuomenę.

Gen. mjr. A. Potapovo dalinių puolimas vyko sunkiau ir dèl gamtinių sąlygų. Nors jau buvo prasidejęs kalendorinis pavasaris, puolimo dieną šiame regione siaute pūga, spaudé šaltis, be to, karius jau buvo išvarginęs ilgas žygis. Minima, kad kai kurie Rusijos daliniai tą dieną jau buvo nužygiavę daugiau nei $50 \mathrm{~km}^{133}$.

Iš karto po Rusijos puolimo Vokietijos karinè vadovybè visomis išgalėmis bandẻ pagausinti Klaipėdos krašte esančias pajègas ir kuo skubiau organizuoti miesto gynybą. Dar kovo $17 \mathrm{~d}$. prieš pietus ị Klaipėdą iš Šilutès atvyko 60 vyrų būrys, vakare - dar 100. Iki vakaro ị miestą buvo atgabenta keletas artilerijos pabūklų, 4 kulkosvaidžiai. Tą pačią dieną nusiųstas pranešimas Vokietijos Baltijos jūros laivyno štabui Gdanske, prašant atsiųsti kreiserị ir taip suteikti paramą miesto gynėjams iš jūros. Deja, buvo gautas neigiamas atsakymas teigiant, kad nèra laisvų laivų, kurie galètų būti atsiųsti ị pagalbą. Rekomenduota kreiptis ị aukščiausiają karinio jūrų laivyno vadovybę Kylyje ${ }^{134}$.

Vis dèlto, nepaisant kiekybinio pranašumo, kovo 17 d. Rusijos kariams nepavyko užimti miesto. Tam galejo sutrukdyti nuovargis, prastos gamtinès sąlygos, o taip pat aktyvus Klaipėdos gynèjų pasipriešinimas. Minima, kad apie 21 val. ìvyko Vokietijos ir Rusijos pajègu susidūrimas. Dèl jau minèto pastiprinimo žmonėmis ir ginkluote Vokietijos pajègos sugebejo atsilaikyti ${ }^{135}$. Per kovo 17 d. kautynes Vokietijos pusė iš viso neteko apie 100 karių $^{136}$.

Kovo 18 d. 1 val. nakties vadovavimą Klaipėdos miesto gynybai ị savo rankas perėmė gen. mjr. fon Ezebekas, su visu savo štabu persikèlęs i Šilutę ${ }^{137}$. Štabas kovo 18 d. rytą i šilutę atvykusias 7-ają ir 8-ają landvero pèstininku

\footnotetext{
132 Ten pat.

${ }^{133}$ Ten pat.

${ }^{134}$ J. Sembritzki, Geschichte des kreises Heydekrug, s. 288.

135 J. Sembritzki, Geschichte des kreises Memel, s. 394.

136 Ten pat, s. 390.

${ }^{137}$ Ten pat, s. 391.
} 
kuopas, vadovaujamas plk. Itn. (?) Konradžio (Conradi), ir 3-iojo Karaliaučiaus landšturmo bataliono 1-ają ir 2-ają kuopas iš karto pasiunte ị Klaipėdą padèti miesto gynèjams. Ryte iš Lauksargių buvo atgabenti dar 2 artilerijos pabūklai ir dislokuoti Vokietijos karių pozicijose į rytus nuo Joniškès kaimo ${ }^{138}$.

Kovo 18 d. iki pietų Rusijos kariai vis dar nebuvo užèmę Klaipėdos miesto, tačiau jų puolimas labai suaktyvejo. Pirmoje dienos puseje nuo Lelių kaimo pusès prasidejo pagrindinių Rusijos pajègų puolimas, remiamas artilerijos pabūklų ugnimi, tačiau jis buvo sulaikytas Vokietijos karių gynybos linijos, besidriekiančios prie Šlapžemių kaimo. Aktyvios Vokietijos karių šautuvų, kulkosvaidžių ir artilerijos pabūklų ugnies apie 7000 priešininko karių pajègos buvo pristabdytos ${ }^{139}$. Tačiau tuo Rusijos pajėgu puolimas nesibaigé. Nereikia pamiršti, kad ju puolimas vyko dviem kryptimis, tad dalị ir taip jau negausių savo pajègų Klaipėdos gynejjai turejjo permesti ị šiaurès rytus nuo miesto. Nuo Palangos pusès žygiuojančią Rusijos karių grupę turëjo sustabdyti vyr. ltn. (?) Kupelio (Kuppel) kariai dviejų artilerijos pabūklų ugnimi. Jie pasitiko priešininką prie Kalotės kaimo. Pastebejję, kad ugnis susilpnèjo, Rusijos kariai tuo pasinaudojo ir vèl pradejjo aktyvų puolimą iš rytų pusès link Sendvario, Joniškés kaimų, taip stengdamiesi patekti ị miestą ${ }^{140}$.

Lemiamas Klaipėdos miesto šturmas prasidejo jau sutemus, tikintis, kad pavyks prisidengti tamsa. Tačiau šiuos planus sužlugdẻ Klaipėdos gynėjai, kurie nukreipė ic puolančius priešininkus akinamą prožektorių šviesą ${ }^{141}$. Taigi gen. mjr. A. Potapovo kariai, lygiai kaip ir jų ginklo broliai Taurageje, turejjo pulti tiesiai link ịsitvirtinusio priešininko. Nors Rusijos pajègos ir įsiveržè ị miestą, tačiau čia jų laukè tikras pragaras: „Iš visu namu ir pasleptuviu vokiečiai beré į mus švino krušą. "142 Vokietijos kariai, atsitraukę i miestą, susimaišè su vietos gyventojais. I įsiveržusią miestan Rusijos kariuomenę imta šaudyti pro namų langus ir gatvių barikadas. Klaipėdoje užvirè gatvių mūšiai ${ }^{143}$. Kai kur kova peraugo ị durtuvų kautynes, o jos virto tikromis skerdynėmis. Nepaisant Klaipėdos gynejjų pastangų, po vidurnakčio mieste jau šeimininkavo Rusijos kariai ${ }^{144}$. Miestą ginančios pajègos buvo per menkos, kad atremtų gausesni priešininką, todėl Vokietijos kariai buvo priversti atsitraukti i Kuršių neriją. Dalinių atsitraukimą turèjo pridengti

\footnotetext{
138 Ten pat.

${ }^{139}$ J. Sembritzki, Geschichte des kreises Memel, s. 391.

${ }^{140}$ Ten pat, s. 392.

${ }^{141}$ Klaipedos paėmimas ir atidavimas. Karo vaizdai // Rygos garsas, 1915 kovo 14 (27), Nr. 30, p. 1. 142 Ten pat.

${ }^{143}$ Kaip paėmė Klaipedą. Rytų karo lauke. Karas // Lietuvos žinios, 1915 kovo 11 (24), Nr. 29, p. 3. ${ }^{144}$ KAA, f. 50, ap. 2, b. 199 , 1. 210.
} 
plk. ltn. Konradžio vyrai ${ }^{145}$. Paskutiniai Vokietijos kariai į Kuršių neriją pasitrauké apie 23 val. ${ }^{146}$ Tiesa, jiems nepavyko to padaryti be nuostolių. Per šias kautynes, pavyzdžiui, vien plk. ltn. Konradžio vadovaujamas 817 karių dalinys neteko 189 kovotojų, daugiau nei 20 proc. viso dalinio ${ }^{147}$.

Tapę Klaipėdos šeimininkais, Rusijos kariai pradèjo siautėti mieste. Gyventojų padètis tapo tragiška. Smulkiau aprašinèti visus baisumus, plèšikavimus, žudynes, gyventojų kankinimą šiame straipsnyje būtų paprasčiausiai nekorektiška. Klaipėdoje buvo įvesta komendanto valanda: nuo 20 val. vakaro iki 6 val. ryto gyventojai privalejjo būti namuose. Parduotuvès galëjo dirbti nuo 7 val. ryto iki 20 val. vakaro ${ }^{148}$. Miesto vaizdas buvo kraupus: išdužusių langų stiklų šukių pilnose gatvėse grūdosi plèšikaujantys Rusijos kariuomenès daliniai, buvo visiškai ištuštintos maisto ir kitokių prekių parduotuvès, susprogdintas vandens bokštas, iš gamyklų paimti ir i Rusiją išvežti visi ịrenginiai. İsiveržę ị Klaipėdos Raudonojo Kryžiaus ligoninę, atèjūnai išvaikè medicinos personalą, nupjovè visus laidus ir taip sutrikdẻ operacinès darbą. Negana to, girtaujantys kariai išgèrè visą spiritą, sunaikino eterio ir chloroformo atsargas ${ }^{149}$. Mieste pasilikusi Klaipèdos burmistrą kartu su trimis jo padèjëjais kovo $19 \mathrm{~d}$. vakare suẻmė ị rotušę atvykę Rusijos kariai ir uždarè kareivinèse ${ }^{150}$. Tiesa, prieš tai pareikalauta sumokèti 5000 rublių, kaip atlygį už patirtus nuostolius užimant miestą. Nustatytas naujas rublio ir markès kursas ${ }^{151}$. Tačiau šie pinigai taip ir nebuvo sumokèti. Pasienyje su Prūsija gyvenantiems lietuviams valstiečiams buvo pavesta prižiūrèti kelis šimtus iš Rytprūsių ūkių rekvizuotų galvijų. Turtingas Klaipedos kraštas liepsnojo gaisruose: „Atvažiavę nuo Palangos pasakoja, kad naktimis Palangos apylinkejje matèsi gaisru peizažai pietvakariu krašte. Ypač gerai buvę galima žiūrèt važiuojant pajūriu iš Palangos į Liepoją. Ten degè prūsų kaimai ir miesteliai. Retkarčiais girdejosi ir tolimas armotu griausmas. " 152

Tai, kad Klaipėdą užėmusios Rusijos pajëgos buvo panašesnès ne i kariuomenès dalinius, o ị pléšikaujančią bandą, patvirtina ir patys Rusijos

\footnotetext{
${ }^{145}$ Klaipėdos iszgascziu dienos // Lietuwiszka ceitunga, 1915 kovo 30, Nr. 34, p. 1.

${ }^{146}$ J. Sembritzki, Geschichte des kreises Memel, s. 393.

147 Ten pat, p. 392.

${ }^{148}$ Klaipėdos iszgascziu dienos // Lietuwiszka ceitunga, 1915 kovo 30, Nr. 34, p. 1.

${ }^{149}$ Martha Pascherat, Der Russeneinfall im ersten Weltkrieg.

${ }^{150}$ Der russische Raubzug gegen Memel. 1914 -1918. Das Archiv zum 1. Weltkrieg.

1511 Vokietijos markè buvo prilyginta 40 Rusijos kapeikų, 1 rublis kainavo 2,5 markès. Žr. Klaipėdos iszgascziu dienos // Lietuwiszka ceitunga, 1915 kovo 30, Nr. 34, p. 1.

152 Klaipėdos paėmimas ir atidavimas. Karo vaizdai // Rygos garsas, 1915 kovo 14(27), Nr. 30, p. 1.
} 
tyrẻjai. Jau 1915 m. gegužès mėn. Rusijos imperijos vidaus reikalų ministro pavaduotojas ir atskirojo žandarų korpuso vadas gen. mjr. Vladimiras Džunkovskis (Владимир Джунковский) paskelbè „agentūrinių žinių suvestinę“. Pagal ją pagrindiniais kaltinamaisiais tapo jau minèti iš laivyno išmesti kariai, kuriais buvo sustiprintos gen. mjr. A. Potapovo pajègos, vadovaujami pirmojo rango kpt. Jurijaus Pekarskio (Юрий Пекарский) ${ }^{153}$. Šio karininko elgesys per visą jo vadovavimo laiką jūrų pèstininkų batalionui apibūdinamas kaip „demoralizuojantis“ ir ,slegiantis“. Reikètų suprasti, kad kpt. J. Pekarskio įtakai pasidavę kariai masiškai pléšikavo. Tiesa, pats kpt. J. Pekarskis dar prieš prasidedant operacijai, daliniui sustojus Liepojoje, neigiamai apibūdino savo karius ${ }^{154}$. Gen. mjr. V. Džunkovskio suvestinejje taip pat išsakoma kritiška nuomonè apie operaciją. Reziumuojama, kad pats planas pulti Klaipèdą visiškai neracionalus ir nepagrịstas, kadangi nesitikèta jos ilgai išlaikyti. Puolimui skirtos pajègos apskritai netinkamos tokiai operacijai vykdyti, ypač neparengti kariauti pėstininkų kare ir labai nedrausmingi jūrų pėstininkai. Nemažai kritikos teko ir Klaipėdą puolusių pajègų vadovybei su gen. mjr. A. Potapovu priešakyje. Teigiama, kad jie „atsidūré toli gražu ne savo vietoje“155. Vokiškuose šaltiniuose užsimenama, kad pats gen. mjr. A. Potapovas nekreipé dėmesio į savo karių pléšikavimą ir jų nesudrausmino ${ }^{156}$. Tiesa, negalime visos kaltès šiuo atveju suversti gen. mjr. A. Potapovui, nes jis bandė suvaldyti padètị. Tik užèmus Klaipėdą, parduotuvių savininkams jau buvo uždrausta pardavinèti alkoholinius gėrimus Rusijos kariams ${ }^{157}$. Savaime suprantama, kad toks nurodymas turejo mažai reikšmès, tad, nesiliaujant girtavimui, buvo įsakyta visus rastus alkoholinius gèrimus supilti ị Danès upę ${ }^{158}$. Tačiau ir tokie bandymai nelabai padejo suvaldyti nedrausmingus, žemos moralès karius. Dar vienas iš bandymų stabilizuoti padètị mieste - ísakymas uždaryti plèšikaujančius karius kareivinèse ${ }^{159}$. Klaipėdos gyventoja, savo akimis mačiusi visus šiuos ivvkkius, patvirtina faktą, kad kovo 20 d., šeštadienį, miestiečiai iš tikrųjų galëjo lengviau atsikvépti1 ${ }^{160}$. Mieste buvo palikta tik nedaug sargybinių.

153 А. Адылов, Третий штурм.

154 М. Лемке, 250 дней в царской ставке 1916, Харвест, 2003, с. 314.

155 Ten pat.

${ }^{156}$ Der russische Raubzug gegen Memel.

${ }^{157}$ Klaipedos iszgascziu dienos // Lietuwiszka ceitunga, 1915 kovo 30, Nr. 34, p. 1.

${ }^{158}$ Martha Pascherat, Der Russeneinfall im ersten Weltkrieg // http://www.memelland-adm.de/ Archiv/20\%20Berichte/Russeneinfall.html

${ }^{159}$ Vyriausybiszkas praneszimas // Lietuwiszka ceitunga, 1915 kovo 30, Nr. 34, p. 2.

${ }^{160}$ Martha Pascherat, Der Russeneinfall im ersten Weltkrieg // http://www.memelland-adm.de/ Archiv/20\%20Berichte/Russeneinfall.html 
Tiesioginiu šio puolimo rezultatu gen. mjr. V. Džunkovskis vadina jau 1915 m. gegužès ménesi platų mastą igijusi Vokietijos pajẻgų puolimą Žematijoje ir Kurše, kadangi iki tol Vokietijos vadovybè, nematydama pavojaus, šiame regione laike tik menkas landšturmo pajègas. Rusijos agresija privertė juos čia sutraukti daugiau nei vieną korpusą reguliariosios kariuomenès karių iš kitų fronto vietų, dèl ko tuo metu kilo grèsmè net ir Rygai ${ }^{161}$. Pažvelgus ị šias išvadas peršasi mintis, kad pačios vadovybès netikejjimas Klaipėdos puolimo tikslingumu galejjo turèti ịtakos ir kariams. Todèl, tikintis greitai atsitraukti, per trumpą laiką buvo stengiamasi prisigrobti kuo daugiau turto. Kita vertus, plèšikavimo Klaipėdoje atvejis šiame kare nèra kuo nors išskirtinis. Rusijos kariuomené plèšikavo ir kitose fronto vietose. Negalime sakyti, kad Vokietijos kariuomenè buvo „šventa“ - daugybę kartų ji elgèsi lygiai taip pat, kaip Tauragès ir Jurbarko apylinkèse, kur netramdoma plèšè ir grobė.

Matyti, kad Klaipèdos miesto užèmimas sukrètė aukščiausiają Vokietijos karinę vadovybę, todèl, už tai keršydama, ji skyrẻ kontribucijas Suvalkų ir Lodzès miestams, be to, pagrasino už kiekvieną Rusijos kariuomenès užimtą miestą ir sodybą Rytų Prūsijoje atitinkamai griuvèsiais paversti 3 miestus ir 3 sodybas ${ }^{162}$.

Kovo 20 d., šeštadienį, daug Klaipèdą okupavusių dalinių turèjo pasitraukti iš miesto. Kai kurie iš jų, kaip jau minèta, buvo uždaryti kareivinèse dẻl pléšikavimų, kiti gavo ịsakymą žygiuoti i pagalbą Tauragès apylinkèse kovojantiems daliniams. Visa tai stengtasi slèpti, kad gyventojai nesugalvotuc pasinaudoti susidariusia palankia situacija. Dėl to visiems Klaipėdos gyventojams kovo $20 \mathrm{~d}$. buvo uždrausta po 14 val. palikti savo namus ${ }^{163}$. Kovo 21 d., sekmadieni, po pietų, Klaipėdą pasiekè nauja Rusijos kariuomenès grupè, kurią sudare 3000 karių. Jie praktiškai iš karto turèjo stoti ị mūšị su tą pačią dieną prie miesto iš pietu pusès priartèjusiais gen. mjr. fon Ezebeko vadovaujamais Vokietijos kariuomenès daliniais ${ }^{164}$. Savaime suprantama, jog aukščiausioji Vokietijos karinė vadovybe negalejjo palikti Klaipėdos tokioje padètyje, ypač kai buvo viešai deklaruojamos idẻjos išvalyti Rytų Prūsijos žemes nuo okupantų ${ }^{165}$. Vokietija ị ši regioną pradejjo

\footnotetext{
${ }^{161}$ А. Адылов, Третий штурм.

${ }^{162}$ Vyriausiojo kariuomenès vado štabo pranešimas. Rytų karo lauke. Karas // Lietuvos žinios, 1915 kovo 18 (31), Nr. 32, p. 3; Klaipėdos paėmimas ir atidavimas. Karo vaizdai // Rygos garsas, 1915 kovo 14(27), Nr. 30, p. 2.

${ }^{163}$ Vyriausybiszkas praneszimas // Lietuwiszka ceitunga, 1915 kovo 30, Nr. 34, p. 2; J. Sembritzki, Geschichte des kreises Memel, s. 394.

${ }^{164}$ Vyriausybiszkas praneszimas // Lietuwiszka ceitunga, 1915 kovo 30, Nr. 34, p. 2

${ }^{165}$ E. Ludendorff, Meine kriegserinnerungen 1914-1918, s. 104.
} 
siųsti papildomus, tačiau jau ne tik landvero ir landšturmo, bet ir reguliariosios kariuomenès dalinius. Taip pat svarus pastiprinimas buvo ị šią kovos veiksmų zoną perkelti pirmieji 6-osios kavalerijos divizijos daliniai ${ }^{166}$. Ši divizija prieš tai padejjo Austrijos-Vengrijos kariams kovoti su Rusija prie Pšasnyšo. Sunkėjant Vokietijos paděčiai šiaurrytiniame Rusijos pasienyje buvo nuspręsta visą 6-ają kavalerijos diviziją perkelti i Žemaitiją.

Puolimas prasidejo apie 18 val. vakaro ir vyko iš pietų pusès, nuo Lypkių kaimo. Nors puolančią kariuomenę pasitiko smarki Rusijos karių šautuvų ir kulkosvaidžių ugnis, tačiau Vokietijos pajègos palyginti greitai stūmèsi i prieki. Ypač kovose pasižymėjo apie 19 val. į miestą įžengęs mjr. fon Nusbaumo (von Nußbaum) vadovaujamas rezervinis batalionas, kuris stojo i gatviu mūšius ${ }^{167}$. Ju metu Rusijos kariai turëjo atsitraukti link šiaurinèje Klaipėdos dalyje esančių kareivinių. Tą dieną Rusijos kariuomenè neteko apie 200 karių. Vokietijos nuostoliai buvo gerokai mažesni - tik apie 20 karių ${ }^{168}$. Vokietijos karių operaciją palengvino ir patys priešininkai. Gavęs informacijos, kad prieš ji telkiami Vokietijos reguliariosios kariuomenès daliniai, gen. mjr. A. Potapovas įsake savo kariams trauktis ${ }^{169}$.

Kovo 22 d. tęsèsi Rusijos karių persekiojimas. Gen. mjr. fon Ezebeko brigada stūmė priešininkus link Kretingos. Skubėdami atsitraukti, Rusijos kariai paliko apie 3000 ị nelaisvę paimtų Klaipėdos krašto gyventojų. Gen. mjr. fon Ezebeko pajėgų dešiniji sparną dengè iš Kuršių nerijos sugrižę plk. Itn. Konradžio kariai. Dvi 6-osios kavalerijos divizijos brigados ir viena baterija, vadovaujamos gen. mjr. (?) fon Selchovo (von Selchow), stūmé priešininkus pro Laugalius, Baukštkaralę iki pat sienos prie Jokūbavo kaimo ${ }^{170}$. Kovo $23 \mathrm{~d}$. innirtingas Vokietijos ir Rusijos karių susirèmimas įvyko prie Palangos. Po jo Rusijos kariai buvo priversti apleisti ir ši miestą ${ }^{171}$. I pagalbą Vokietijos kariams atvyko jūru pajègos. Nors spaudoje minima, kad persekiojant atsitraukiančius dalinius iš viso dalyvavo 7 dideli laivai ir 28 minininkai ${ }^{172}$, vargiai tikètina, kad tokios gausios pajègos tam būtų mestos . Iš viso persekio-

${ }^{166}$ Der Erste Weltkrieg-1914/1918// http://www.1914-18.info/erster-weltkrieg.php?u=349\&info $=6$. Kavallerie-Division \&start $=70$

${ }^{167}$ J. Sembritzki, Geschichte des kreises Heydekrug, s. 288.

168 М. Лемке, 250 дней в царской ставке 1916, Харвест, 2003, с. 313; Vyriausybiszkas praneszimas // Lietuwiszka ceitunga, 1915 kovo 30, Nr. 34, p. 2; J. Sembritzki, Geschichte des kreises Memel, s. 398.

${ }^{169}$ А. Адылов. Третий штурм.

${ }^{170}$ J. Sembritzki, Geschichte des kreises Memel, s. 398.

${ }^{171}$ KAA, f. 50, ap. 2, b. 199, 1. 240.

${ }^{172}$ Vyriausiojo kariuomenès Vado štabo pranešimas. Rytų karo lauke. Karas // Lietuvos žinios, 1915 kovo 15 (28) d., Nr. 31, p. 3. 
jant Vokietijos kariai ị nelaisvę paėmė apie 500 Rusijos karių, užvaldẻ 3 artilerijos pabūklus, 3 kulkosvaidžius ir kelis vežimus su amunicija ${ }^{173}$.

Gyventojai pasibaisėję žiūrèjo ị nusikamavusius, persekiojamus Rusijos karius: „Tą nuotaika darlabiau prislègé Gaubių kalnuose, pačiame kelio viduryje tarp Skuodo ir Mosèdžio sutiktas rusu pèstininku bürelis. Kareiviai buvo labiau $i$ šmèklas panašūs, o ne i žmones <...> Ta bežodinè ir begyvybine masè praslinko lyg elgetu būrys. Tačiau visi èjo rikiuotejje, pačiu kelio viduriu, kur daugiausia buvo purvo. Buvo aišku, kad jie bèga nuo besiartinančių vokiečių. " ${ }^{174}$

Sèkmingą tolesni Rusijos karių persekiojimą teko nutraukti gavus žinių apie Vokietijos pajègų pralaimèjimą prie Tauragès. Po Tauragès užèmimo kovo 19 d. gen. mjr. A. Apuchtino daliniai buvo sustabdyti prie Lauksargių. Vokietijos pajègos buvo ịsitvirtinusios nuo Jūros upés, prie Oplankio kaimo, einant i šiaurę iki pat Tauragès-Tilžès kelio. Jos saugojo šị strategiškai svarbų kelią nuo Rusijos karių bandymo veržtis ị priekį. Po labai atkaklių, praktiškai be atvangos vykstančių mūšių Vokietijos kariai turèjo pasitraukti iš Lauksargių kovo $22 \mathrm{~d} .{ }^{175}$

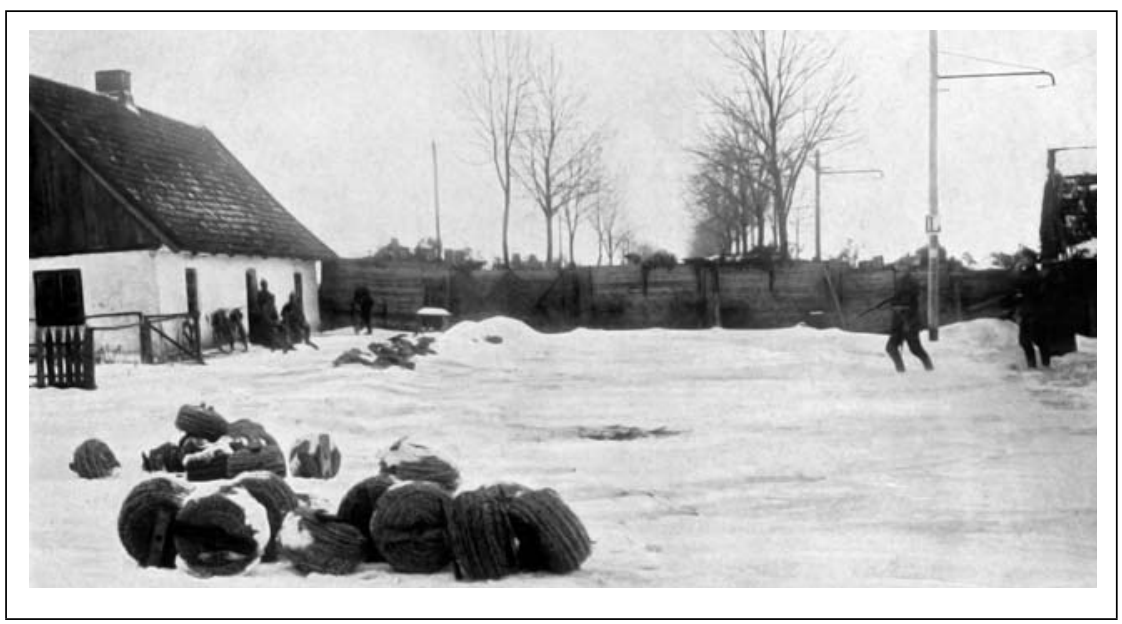

Vokietijos karių barikados, pastatytos siekiant sustabdyti Rusijos pajėgų puolimą link Tilžès. 1915 m. pavasario pradžia (VDKM)

Tiesa, šiame fronto ruože kovojantys Vokietijos kariai pagaliau sulaukè

${ }^{173}$ Der russische Raubzug gegen Memel.

${ }^{174}$ A. Nezabitauskis, Karas mūsų žmonių nepalaužè // Lietuva Didžiajame kare, sudar. P. Ruseckas, Vilnius, 1939, p. 44.

${ }^{175}$ KAA, f. 50, ap. 2, b. $199,1.241$. 
pastiprinimo. Po 30 valandų kelionès traukiniu iki Tilžès ir 24 kilometrųžygio pésčiomis kovo $23 \mathrm{~d}$. vakare kovos veiksmų zoną pasiekė mjr. fon (?) Horsto (von Horst) vadovaujamas rezervinis pèstininkų batalionas iš Ščecino ${ }^{176}$. Iš šiaurès vakarų pusès, išstūmę priešininkus iš Klaipèdos, tą pačią kovo 23-iają atžygiavo gen. mjr. fon Ezebeko kariai.Vakare prasidèję mūšiai tęsèsi visą naktį. Rusijos žvalgybai pastebejus, kad Vokietijos pajėgos sustiprejjo, nuspręsta trauktis atgal link Tauragès ${ }^{177}$. Naktị iš kovo 26-osios i 27 -ają iš šiaurinès Rytų Prūsijos dalies pasitraukè paskutiniai Rusijos kariuomenès daliniai ${ }^{178}$. Tai buvo lemiamas kovų etapas, kadangi čia èmé plaukti vis nauji Vokietijos kariuomenès daliniai. Tiesa, kaip ir Rusijos kariams prie Klaipėdos, Vokietijos kariams prie Tauragès puolimą apsunkino gamtinės sąlygos. Kovo pabaigoje staiga atšilus orams, prasidèjo atodrèkis, dèl ko labai pablogèjo keliai ${ }^{179}$. Daliniams judèti pasidarè itin sunku, nekalbant jau apie artilerijos pabūklų ir amunicijos vežimų transportavimą. Kai kuriose vietose artilerijos pabūklus teko palikti, nes toliau gabenti buvo tiesiog neįmanoma. Nemuno žemupyje upių ir upelių vandens lygis pakilo tiek, kad pèstininkai brido iki juosmens vandenyje ${ }^{180}$.

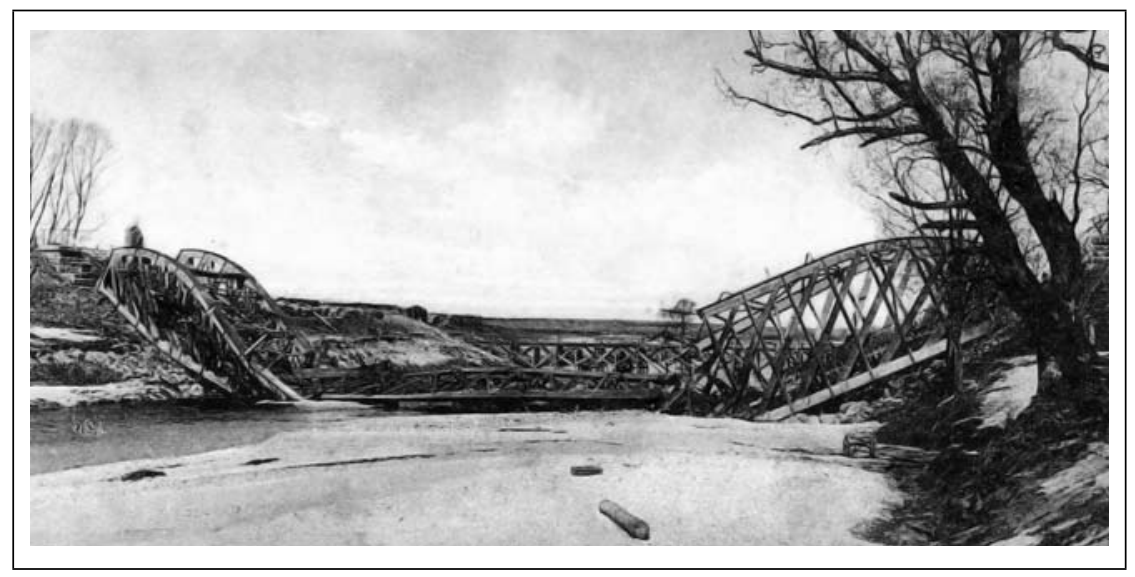

Pirmojo pasaulinio karo metu susprogdintas tiltas per Jūros upę prie Tauragès. $1915 \mathrm{~m}$. pavasario pradžia. Iliustracija iš Tauragès krašto muziejaus rinkinių (toliau - TKM)

${ }^{176}$ War Chronicle. War Journal. Soldiers, letters, pictures of the war, p. 3 //; F. Immanuel, Der Krieg im Herbst und Winter im Osten.

177 С. Бирюк, 68-я пех. дивизия в Первой мировой войне // Рейтар.

${ }^{178}$ KAA, f. 50, ap. 2, b. 199, 1. 291-292.

${ }^{179}$ Schlachtfelder in Ostpreussen, s. 154.

${ }^{180}$ War Chronicle. War Journal. Soldiers, letters, pictures of the war, p. 4. 
Puolančiajaipuseiteko nelengvaužduotis-pereitikeliąužtvėrusią Ežeruonos upelio slėnio juostą. Dèl to Rusijos kariai turejjo daugiau laiko issitvirtinti ${ }^{181}$. Iveikusių šią kliūtị Vokietijos karių laukè dar rimtesnè užduotis - pereiti ištvinusią Jūros upę. Vokietijos inžineriniai daliniai pradejo statyti perkèlą. Ir vèl gamtinès sąlygos jiems buvo palankios - pradejjo vèsti oras ${ }^{182}$. Kol inžineriniai daliniai statė tiltą, puolimo parengimą vykdė Vokietijos artilerija. Kovo 27 ir 28 dienomis Taurage buvo apšaudoma iš artilerijos pabūklų, dèl to ypač nukentèjo pietinè miesto dalis ${ }^{183}$. Tiesa, šie šaudymai neliko be atsako. Vokietijos karių bandymus užimti Tauragès miestą labai apsunkino Rusijos artilerijos ugnis, kuri buvo koreguojama iš Tauragès bažnyčios bokšto. Būtent dèl šios priežasties šis statinys tapo labai svarbiu Vokietijos artileristų taikiniu ${ }^{184}$. Kovo 27 d. po pusiaudienio virš Tauragès miesto pasirodė vokiečių žvalgybos lèktuvas. Apsukęs kelis ratus apie miestą, jis nuskrido. Netrukus Vokietijos pajëgos pradëjo labai smar-kiai šaudyti iš artilerijos pabūklų ${ }^{185}$. Kovo 28 d. ugnis šiek tiek susilpnèjo, pasidarè retesnè, tačiau apšaudymo metu pagaliau buvo sunaikintas labai svarbus Rusijos kariams stebejjimo punktas - Tauragès bažnyčia ${ }^{186}$.

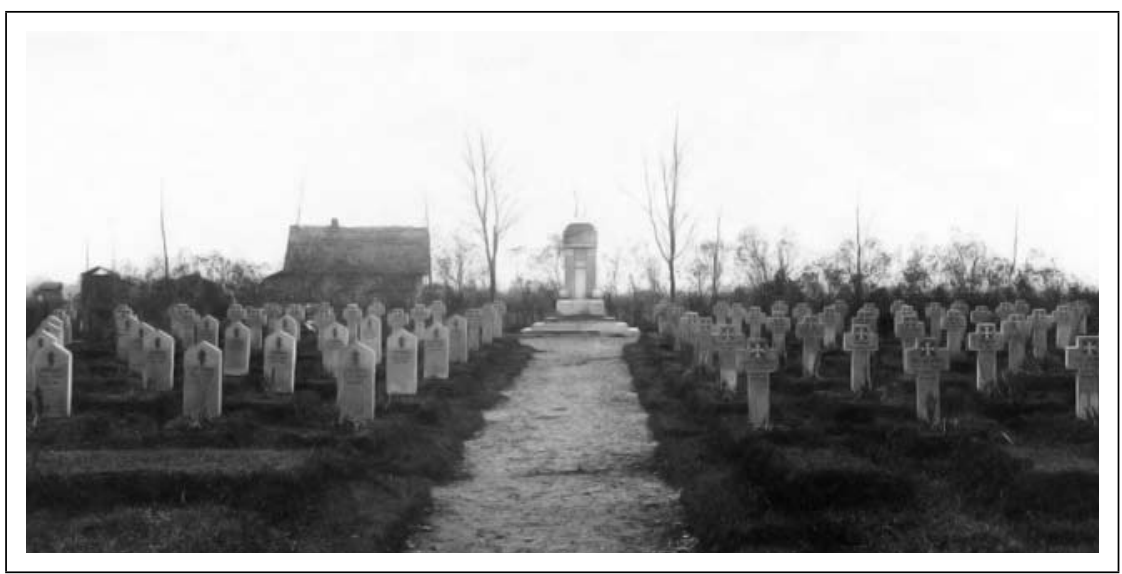

Vokietijos ir Rusijos karių, žuvusių Tauragès apylinkèse

Pirmojo pasaulinio karo metu, kapai. Tauragè XX a. 3-4 deš. (TKM)

\footnotetext{
${ }^{181}$ Ten pat

${ }^{182}$ Ten pat.

${ }^{183}$ KAA, f. 50, ap. 2, b. 199, 1. 298-299, 309.

${ }^{184}$ Ten pat, 1. 291-292.

${ }^{185}$ KAA, f. 50, ap. 2, b. 199, 1. 299

186 Ten pat, 1. 314.
} 
Kovo 28 d. Vokietijos inžineriniai daliniai baigè statyti tiltą per Jūros upę ir taip atvėrè kelią savo daliniams ị Tauragès miestą ${ }^{187}$. Naktị iš kovo 28-osios i 29-ają, iš karto po vidurnakčio, vèl prasidejo stiprus ịsitvirtinusių Rusijos karių pozicijų apšaudymas iš artilerijos pabūklų ${ }^{188}$. Iš karto po jo vyko péstininkų ataka. Apie 3 val. nakties Vokietijos kariai persikėlè per Jūros upę ties Pajūrio kaimu ir pradejo Rusijos karių pozicijų šturmą. Puolimui vadovavo mjr. (?) fon Nusbaumas, jau spèjęs pasižymèti mūšiuose dèl Klaipèdos ${ }^{189}$. Vokietijos kariai ketino apsupti Rusijos karių pozicijas ir tada suduoti lemiamą smūgị. Rusijos pusé, pastebejusi, kur link krypsta tolesné operacijos eiga ir noredama išvengti visiško sutriuškinimo, buvo priversta trauktis link Kelmès, t. y. užleisti priešininkui Tauragès miestą. Tačiau šis atsitraukimas jau buvo pavėluotas, kadangi Vokietijos kariai spejjo patekti i priešininko užnugarį. Taip dalis nespejusių atsitraukti Rusijos pajėgu atsidūrè apsuptyje ${ }^{190}$. Rusijos kariai buvo priversti veržtis iš apsupties ir dèl to patyrè daug nuostolių ${ }^{191}$. Vokiškuose šaltiniuose minima, kad po mūšio kovos lauke liko apie 500 nukautų Rusijos karių ir dar tiek pat buvo paimta i nelaisvę ${ }^{192}$. Per šias kovas ypač nukentejjo Tauragès miestas. Jis praktiškai buvo visiškai sudegintas ${ }^{193}$. Tai, kad Vokietijos kariai nepagailejo Tauragès, ịtakos galèjo turèti ir barbariškas Rusijos karių elgesys užimant Klaipėdą.

Taigi, taip nesėkmingai baigèsi Rusijos pajègų žygis ị Tilžę. $1915 \mathrm{~m}$. pradžios kovos Vakarų Lietuvoje, Vokietijos ir Rusijos pasienyje, buvo vienas iš paskutinių epizodų tais metais, kai Rusijos kariuomenei pavyko pastumti frontą $i$ vakarus, ir apskritai paskutinis kartas per visą Pirmaji pasaulinį karą, kai jai pavyko įžengti ì Rytų Prūsiją iš šiaurès pusès. Norédami tęsti sèkmingą puolimą, vokiečiai ir toliau stiprino savo pajègas šiaurinèje Rytprūsių dalyje, o jau 1915 m. balandžio mėnesi pradėjo plataus masto puolimą i Vakarų Lietuvą ir Kuršą.

\footnotetext{
${ }^{187}$ War Chronicle. War Journal. Soldiers, letters, pictures of the war. p. 4. ${ }^{188}$ KAA, f. 50, ap. 2, b. 199, 1. 314.

${ }^{189}$ War Chronicle. War Journal. Soldiers, letters, pictures of the war. p. 4.

${ }^{190}$ KAA, f. 50, ap. 2, b. 199, 1. 316.

${ }^{191}$ Ten pat, 1. 317.

${ }^{192}$ War Chronicle. War Journal. Soldiers, letters, pictures of the war, p. 4.

${ }^{193}$ KAA, f. 50, ap. 2, b. 199, 1. 342.
} 


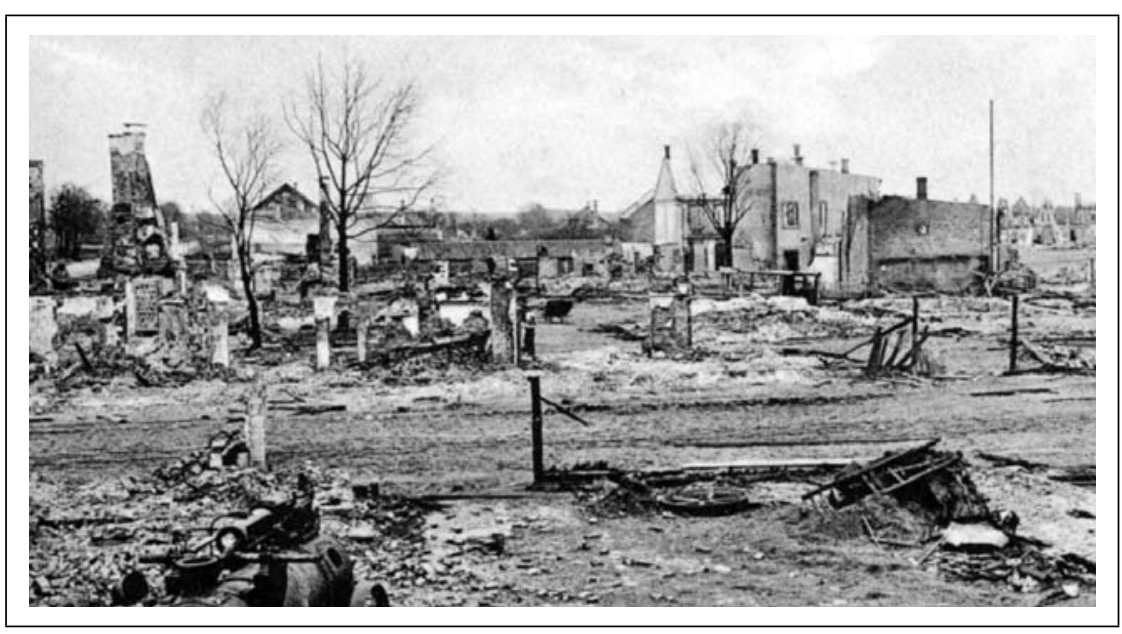

Pirmojo pasaulinio karo kovų suniokotas Tauragès miestas. 1915 m. pavasaris (TKM)

\section{IŠVADOS}

1. Pirmojo pasaulinio karo pradžioje prasidejo nedideli pasienio apsaugos dalinių susiremimai ir ị šiaurès rytus nuo Nemuno žemupio per Lietuvos žemes besidriekiančiame Rusijos ir Vokietijos pasienyje. Rugpjūčio antroje pusejje puolimą pradejjusi Vilniuje suformuota 1-oji Rusijos armija privertė Vokietijos 8-ają armiją pralaimèti prie Stalupènų ir Gumbinès. Stengiantis atsilaikyti prieš gausesnị priešininką, šiai Vokietijos armijai ị pagalbą teko pasitelkti visus įmanomus dalinius, taip pat ir esančius šiauriniame pasienyje. Šiame regione dislokuoti Rusijos kariai, pasikeitus jègos pusiausvyrai, surengé sėkmingą puolimą, todẻl jau rugpjūčio pabaigoje buvo užimtas Tilžès miestas, peržengta Nemuno upe ir ịsiveržta ị Rytų Prūsijos teritoriją iš šiaurès pusės.

2. Rusijos kariuomenei patyrus nesėkmę prie Mozūrijos ežerų, Vokietija galèjo permesti papildomus dalinius ị šiaurrytinị pasienị ir ne tik išstumti Rusijos karius iš Tilžès, bet ir rugsejjo viduryje užimti Rusijos pasienio miesteli Tauragę. Vokietijos karinei vadovybei daugiau dèmesio pradejjus skirti pietinei Rytu fronto daliai, Rusija tuo pasinaudojo ir lapkričio pradžioje sugebejo atsikovoti Tauragę ir šiaurines Rytų Prūsijos žemes.

3. 1915 m. pradžioje Vokietija ruošèsi igyvendinti naujus planus - suduoti lemiamą smūgi Rusijos kariuomenei. Remiantis jais, Rusijos 10-oji armija turejo būti apsupta puolant jos kraštinius sparnus ir veržiantis į užnugarị. Taip pat nuspręsta galutinai išstumti Rusijos kariuomenę iš Rytų 
Prūsijos žemių. Vasario viduryje prasidejo naujas Vokietijos pajègų puolimas nuo Tilžès pusės Tauragès kryptimi. Jis pavyko - Rusijos kariai buvo ne tik nustumti atgal už valstybès sienos, bet jau antrą kartą šio karo metu užimtas Tauragès miestas.

4. Rusija, siekdama reabilituotis po visos virtinès nesèkmių, taip pat noredama apsaugoti savo 10-osios armijos dešiniji sparną nuo gresiančios apsupties, sutelkusi papildomas pajègas, kovo viduryje kontratakavo priešininką iš karto dviem kryptimis - Klaipedos ir Tauragès.

5. Nepaisant kiekybinès persvaros, Rusijos kariams įveikus aktyvų Klaipẻdos miesto iggulos ir gyventojų pasipriešinimą, tik kovo $18 \mathrm{~d}$. vẻlų vakarą pavyko užimti miestą. Iš karto užimtoje Klaipėdoje prasidèjo plèšikaujančios Rusijos kariuomenès siautėjimas. Tai vẻliau sulaukẻ plataus atgarsio ne tik Vokietijos, bet ir Rusijos kariuomenès vadovybès aukščiausiuose sluoksniuose. Praejjus vos kelioms dienoms, kovo $21 \mathrm{~d}$. Vokietija, sutelkusi papildomus, taip pat ir reguliariosios kariuomenès, dalinius, išstūmė pakrikusius Rusijos karius. Tolesnèmis dienomis vyko atsitraukiančios Rusijos kariuomenès persekiojimas.

6. Tuo pat metu, kai vyko Klaipèdos puolimas, kita Rusijos kariuomenès grupè kovo $18 \mathrm{~d}$. atsikovojo Tauragès miestą, tačiau nesugebejjo palaužti Vokietijos pajègų pasipriešinimo ir sèkmingai nužygiuoti iki pat Tilžès. Išstūmę priešininkus iš Klaipėdos, Vokietijos kariai buvo perdislokuoti ị šị rajoną ir kartu su naujai atvykusiomis papildomomis pajègomis kovo pabaigoje atsièmè visas teritorijas, kurias buvo užėmę iki tol.

7. 1915 m. pradžios kovos Vakarų Lietuvoje, Vokietijos ir Rusijos pasienyje, buvo paskutinis epizodas per visą Pirmaji pasaulinį karą, kai Rusijos kariuomenei pavyko pastumti frontą i vakarus ir įsiveržti i Rytų Prūsijos žemes iš šiaurès pusès. Ši Rusijos operacija buvo vienas iš veiksnių, privertusių Vokietijos kariuomenę sutelkti didesnes pajëgas per Pietvakarių Lietuvą besidriekiančiame Vokietijos ir Rusijos pasienyje ir pradèti naują didelio masto operaciją, kuri lemé, kad vos per kelis ménesius buvo okupuota visa dabartinès Lietuvos teritorija. 


\title{
ACTIONS DE LA PREMIÈRE GUERRE \\ MONDIALE EN LITUANIE \\ OCCIDENTALE - DANS LES CONFINS \\ DE L'ALLEMAGNE ET DE LA RUSSIE - \\ AU DÉBUT DES ANNÉES 1915
}

\author{
Marius Pečiulis, \\ Musée militaire de Vytautas le Grand
}

Dans la direction de nord-est de l'aval de Nemunas, les confins de l'Allemagne et de la Russie traçants les terrestres lituaniennes d'aujourd'hui, sont devenus un champ des batailles persistantes dès le début de la Première guerre mondiale. En premiers jours d'août des années 1914, les luttes des bataillons de la sécurité frontalière se sont opérées. Ces luttes se développaient à plus grande échelle dans la deuxième moitié du mois après avoir commencé l'attaque pour la première armée constituée à Vilnius. Cette armée a forcé la $8^{\text {ème }}$ armée de l'Allemagne à perdre la lutte auprès Stalupènai et Gumbinè. En s'efforçant de s'élever contre le contradicteur plus nombreux, l'armée allemande a reçu des secours de tous les bataillons possibles, ceux dans les confins du nord aussi. Dans cette région, après avoir changé l'équilibre des pouvoirs, des soldats de la Russie disloqués ont organisé l'attaque fructueuse et grâce à cette attaque, à la fin d'août ils ont occupé la ville de Tilžè et après avoir franchit la rivière de Nemunas, ils ont envahit à la profondeur du territoire de Prusse orientale de la coté du nord. Néanmoins, cette fortune était à courte échéance. Après avoir craqué les forces principales de l'armée de la Russie auprès des lacs de Mozūrija, 1'Allemagne pouvait ramener des bataillons supplémentaires aux confins de nord-est et regagner des territoires perdues ainsi qu'au milieu de septembre - occuper la cité frontalière de Russie appelé Tauragè. Cependant, après un court temps, la bascule de la guerre s'est tournée en faveur de la Russie. Au moment où le commandement des armées de l'Allemagne commençait à veiller sur une partie australe du front oriental, la Russie alors profitait cette situation et au début du novembre a regagné Tauragè et les terrestres de Prusse orientale.

En cas d'un échec de réalisation soudaine de l'idée militaire, au début des années 1915 le commandement des armées de l'Allemagne était obligée 
d'élaborer un nouveau plan avec lequel il pourrait donner un coup décisif pour l'armée de la Russie. Á base de ce plan, la $10^{\text {ème }}$ armée de la Russie constitué d'une nouvelle manière et disloquée au territoire de la Lituanie d'aujourd'hui, devait être obsidionale en attaquant ses flancs extrêmes et en s'élançant en arrière. La réalisation de ce plan a commencé au milieu de février. Comme un des segments de ce plan - l'attaque des forces de l'Allemagne du coté de Tilžè dans la direction de Tauragè au milieu de février. Grace à l'attaque successive, des soldats de l'Allemagne avaient occupé la ville de Tauragè la deuxième fois lors de cette guerre.

La Russie, prétendant de réhabiliter après la queue de tous les échecs, et désirant de préserver le flanc droit de la $10^{\text {ème }}$ armée contre l'encadrement menaçant, au milieu de mars, après avoir réunit des forces supplémentaires, elle a contre-attaquée son ennemi dans les deux directions en même temps - direction de Klaipèda et de Tauragė. Malgré la prépondérence quantitative, les soldats de la Russie forcaient la rébellion des habitants et de la garnison de la ville de Klaipeda, et juste tard dans la nuit du 18 mars ils ont occupé la ville. Dans la ville de Klaipèda, le déchaînement écumant de l'armée russe commençait. Ce fait rentrait une vaste répercussion dans les couches plus hautes du commandement des armées de l'Allemagne outre que de la Russie. En même temps, un autre groupe de l'armée russe le 18 mars regagnait la ville de Tauragé, mais elle ne pouvait pas ébranler de la rébellion des forces de l'Allemagne ainsi que marcher successivement jusqu'à Tilžè. Après avoir passé quelques jours, le 21 mars l'Allemagne, après avoir disloqué des bataillons de l'armée régulière dans cette région, supplantait des soldats de la Russie détraqués hors Klaipėda, et le 29 mars regagnait encore une fois la ville de Tauragè.

Au début des années 1915, les batailles dans la Lituanie occidentale, aux confins de l'Allemagne et de la Russie, étaient le dernier épisode vers toute la Première guerre mondiale quand l'armée de la Russie réussissait de pousser le front à l'Ouest et envahir aux terrestres de Prusse orientale du coté nordique. Cette opération de la Russie était l'une des actions qui forçaient l'armée de l'Allemagne à masser des troupes plus grandes aux confins de l'Allemagne et de la Russie traçants en long de la Lituanie sud-ouest, et à commencer une nouvelle opération de grande échelle, qui destinait que le territoire de la Lituanie d'aujourd'hui était toute occupée juste durant quelques mois. 


\title{
THE FIRST WORLD WAR OPERATIONS IN WEST LITHUANIA - GERMAN-RUSSIAN BORDER IN THE BEGINNING OF 1915
}

\author{
Marius Pečiulis \\ Vytautas The Great War Museum
}

In the north-east of the Nemunas River, through the today's lands of Lithuania, there lying border line between Russia and Germany became a fierce battle field from the very beginning of the First World War. Already in early days of August in 1914, there took place the clashes between border guard divisions, which gained a wider scale in the second half of August, when the Vilnius built-up $1^{\text {st }}$ Army initiated the attack. The latter forced the German $8^{\text {th }}$ Army to lose near localities of Stalupenai and Gumbine. Trying to resist the numerous opponent forces, this German army had to address for help all the available units, as well as those dislocated at the northern border. In this region the deployed Russian troops, after change of the balance of power, committed a successful attack, thanks to which, at the end of August the Tilze town was occupied and the territory of East Prussia from the north has been intruded into after crossing the Nemunas River. However, this success was short term. After the main Russian military forces met with the failure in the main event at the Masurian Lakes, Germany was able to throw the additional units at the northeast border and not only to recover the lost territories, but also to take the town of Taurage at the Russian border in mid-September. But soon after, the scales of war once again turned in favour of Russia. After the German military authorities began granting more attention to the southern part of the Eastern Front, Russia benefited from it and in the beginning of November it was able to regain Taurage town and the northern lands of East Prussia.

Failing to implement the idea of the sudden war, in the beginning of 1915 the German military command was forced to develop a new plan, which implementation would hit the finishing stroke to the Russian military army. According to the plan, the newly developed and deployed on the present territory of Lithuania the Russian 10th Army was to be surrounded by attacking its outside wings and taking in the reverse. Implementation of 
this plan began in mid-February. One of the segments of this plan was the attack of the German forces from Tilze side in the direction of Taurage in mid-February. Thanks to the successful attack the German troops occupied the Taurage city for the second time during this war.

Striving to rehabilitate its status after total series of setbacks, Russia, also trying to safeguard the right-wing of its $10^{\text {th }}$ Army from threat of encirclement, united the additional forces and in mid-March counterattacked the enemy from two directions at once - Klaipeda and Taurage. Despite the quantitative preponderance only in the late evening of the $18^{\text {th }}$ of March the Russian troops managed to occupy the city after they had overcome the active resistance of the Klaipeda city crew and population. Rage of marauding Russian troops has started in Klaipeda. Later it received a wide response not only in Germany, but also in the highest layers of the Russian military leadership. At the same time another group of the Russian troops regained the Taurage town on $18^{\text {th }}$ of March, but failed to break the German resistance forces and did not succeed to reach Tilze. Just few days after, the Germany re-dislocated the regular army units to this region and on $21^{\text {st }}$ of March pushed the scattered Russian troops away from Klaipeda and on March 29 it reoccupied Taurage town.

Fighting at the German-Russian border in West Lithuania in the beginning of 1915 was the last episode during the First World War, when the Russian troops managed to push the front to the west and invade the lands of East Prussia from the north. The Russian operation was one of the factors that forced the German Army to mobilize the larger forces at the German-Russian border trailing over the present south-western territory of Lithuania and to launch a new large-scale operation, which resulted in occupation of the entire present territory of Lithuania only in few months. 